\title{
Miocene stable isotopic stratigraphy and magnetostratigraphy of Buff Bay, Jamaica
}

\author{
KENNETH G. MILLER Department of Geological Sciences, Rutgers University, Piscataway, New Jersey 08855 and Lamont-Doherty \\ Earth Observatory, Palisades, New York 10964 \\ JAMES D. WRIGHT Lamont-Doherty Earth Observatory, Palisades, New York 10964 \\ MICKEY C. VAN FOSSEN Department of Geological Sciences, Rutgers University, Piscataway, New Jersey 08855 \\ DENNIS V. KENT Lamont-Doherty Earth Observatory, Palisades, New York 10964
}

\section{ABSTRACT}

Previously reported biostratigraphic relationships from middle-upper Miocene sections exposed near Buff Bay, Jamaica $\left(18^{\circ} \mathrm{N}\right.$, tropical bioprovince), differ from the subtropical North Atlantic (Sites 563 and 558). Time scales for this interval rely on correlations established at these subtropical sites, and the differences with the tropical section have implications to global correlations. Planktonic foraminiferal Zones N13 and N15 are thick at Buff Bay but are virtually absent at Sites 563 and 558; nannofossil Zone NN9 is associated with Zone N15 and uppermost Zone N14 at Buff Bay but is associated with Zone N16 at the other sites. Magnetostratigraphic data presented here further complicate the interpretation: Zone NN9 is associated with a thick normal magnetozone at Sites 563 and 558; at Buff Bay, it is associated with a thick reversed magnetozone. Although a secondary magnetization at Buff Bay makes it difficult to identify confidently Miocene normal magnetozones, the thick reversed magnetozone most likely represents the paleomagnetic field and correlates with Chron C5r. The magnetobiostratigraphic relationships require either diachrony of taxa or two mutually exclusive hiatuses in Jamaica and the North Atlantic.

We address this problem by analyzing benthic foraminiferal $\delta^{18} \mathrm{O}$ and $\delta^{13} \mathrm{C}$ from the Buff Bay section. These isotopic data allow us to evaluate three hypotheses that reconcile the magneto-, bio-, and isotopic stratigraphic data and conclude that the first and last occurrences of five taxa were diachronous by $\sim 0.3-0.5 \mathrm{~m} . \mathrm{y}$. between tropical and subtropical locations. This requires revised age estimates for late middle to early late Miocene biostratigraphic datum levels. We suggest that the ranges of several taxa are useful for endemic tropical or subtropical zonations, but correlations between the low and midlatitudes were affected by an increase in latitudinal thermal gradients during the late middle Miocene. However, we admit that further studies are needed before this issue is resolved.

\section{INTRODUCTION}

\section{Neogene Correlations}

Neogene chronologic resolution has been greatly improved in the past decade because of two major advances. The first is the integration of multiple microfossil biostratigraphic zonations, isotopic stratigraphy, and magnetostratigraphy (for example, Berggren and others, 1985; Miller and others, 1985; Wright and Miller, 1992), providing first-order correlations of fossils and isotopic variations to the geomagnetic polarity time scale (GPTS). These calibrations provide independent means of evaluating biostratigraphic problems and of testing the time scale as new correlations are established. The second advance is the application of astronomical tuning to the Plio-Pleistocene record (for example, Imbrie and others, 1984; Shackleton and others, 1990). The use of orbital tuning provides a very accurate time scale ( $\sim 5$ k.y. resolution; Imbrie and others, 1984). Recent efforts have begun to extend the orbital time scale to the Miocene (for example, Hilgen, 1991; Shackleton and others, in press). Such efforts require a relatively precise magnetobiostratigraphic framework against which the astronomical tuning can be applied (for example, Hilgen, 1991).

Although Neogene stratigraphic resolution has been greatly improved, there are a few intervals where stratigraphic problems cause large uncertainties in correlations. A good example is provided by the late middle to early late Miocene discussed in this paper. Time scales developed over the past 20 yr (Fig. 1) show differences of 1-2 m.y. for this interval among foraminiferal zones, nannofossil zones, magnetochrons, and numerical ages. There are four reasons why such large (up to $22 \%$ ) discrepancies occur and still plague stratigraphic correlations:

(1) Relationships between foraminiferal and nannofossil zonations have varied among publications (for example, Fig. 1); this is due not only to varying taxonomic and stratigraphic interpretations, but also to diachronous and geographically restricted ranges. Our results from Jamaica directly address the problem of diachrony of ranges for this interval.

(2) Relationships between magnetozones established in piston cores ("Epochs" 9-12 of Foster and Opdyke, 1970; Ryan and others, 1974) and chrons developed from seafloor spreading anomalies (for example, Heirtzler and others, 1968; LaBrecque and others, 1977; Berggren and others, 1985; Cande and Kent, 1992) have been controversial. This is particularly relevant to the late middle Miocene interval discussed here (Fig. 1). Foster and Opdyke (1970) first correlated late Miocene "Epoch" 11 with marine magnetic Anomaly 5 (= Chron C5 of the GPTS). In contrast, Ryan and others (1974) suggested that "Epoch" 9 was correlated with Anomaly 5. Miller and others

Data Repository item 9449 contains additional material related to this article.

Geological Society of America Bulletin, v. 106, p. 1605-1620, 11 figs., 1 table, December 1994. 


\section{Berggren and \\ Van Couvering (1974) \\ Barron and others (1985) \\ Haq and others (1987) \\ Berggren and \\ Cande and \\ "9-5" \\ "11-5" \\ others (1985) \\ Kent (1992)}
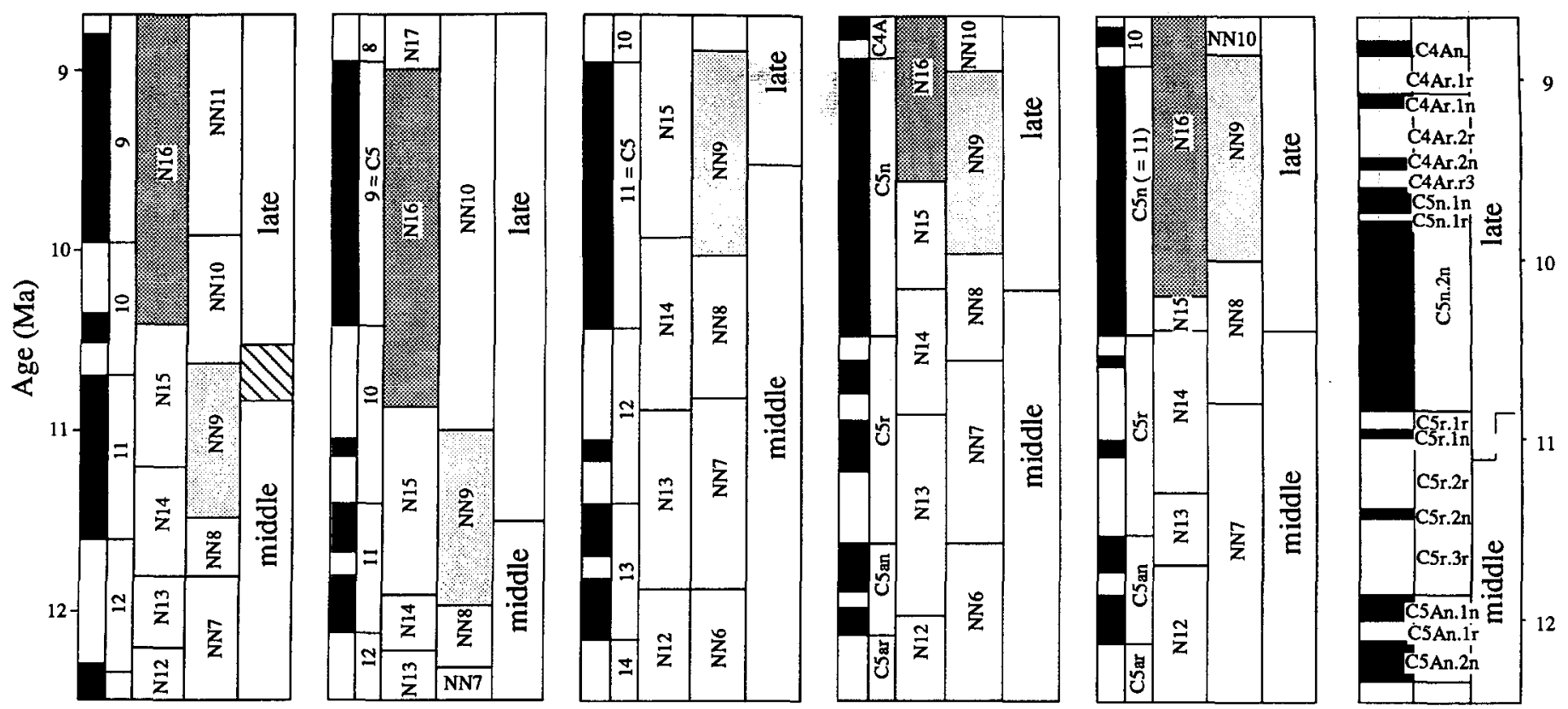

Figure 1. Comparison of time scales for the late middle to early late Miocene illustrating the variable position of Zone NN9 (light stipple) to planktonic foraminiferal Zone N16 (heavy stipple) and the GPTS (black normal, white reversed). Modified after Miller and Kent (1987). References: Berggren and Van Couvering (1974) based on biochronology; Barron and others (1985) based on second-order magnetobiostratigraphic correlations and assuming that "Epoch" 9 is equivalent to Chron C5n; Barron and others (1985) assuming correlation of "Epoch" 11 with Chron C5n; Haq and others (1987) based on second-order magnetobiostratigraphic correlations in this time interval; Berggren and others (1985) based on first-order magnetobiostratigraphic correlations of Miller and others (1985b); Cande and Kent (1992) based on magnetochronology.

Note the changing position of nannofossil and foraminiferal zonal boundaries, the differences between 9-5 versus 9-11 magnetochronology, and the relationships to the most recent GPTS of CK92.

(1985) used biostratigraphic relations at North Atlantic subtropical Site 563 to suggest that "Epoch" 11 at piston core RC12-65 (Foster and Opdyke, 1970 and Ryan and others, 1974) correlates with Anomaly 5. This results in a difference of $\sim 1-2$ m.y. between time scales based on " $9-5$ " versus "9-11" correlations (Fig. 1), but this recorrelation may not be valid if the Site 563 record has hiatus in Chron $\mathrm{C} 5$ as suggested by Aubry (1993).

(3) Numerical calibrations of the GPTS have varied. This accounts for $<1$ m.y. of discrepancies among time scales (Fig. 1) but cannot account for biostratigraphic problems discussed here.

(4) Correlations of the unit stratotype Tortonian (lower upper Miocene) are uncertain because it is not suitable for detailed magnetobiostratigraphic studies, and there is a large gap between the base of the Tortonian (= base of the upper Miocene) and the top of the Serravalian unit stratotype
(= upper middle Miocene) (references in Berggren and others, 1985).

We believed that efforts in the mid-1980s (summary in Berggren and others, 1985) had solved some of the problems with this vexing interval. However, we were concerned because the only first-order correlations between bio- and magnetostratigraphy for this interval that were used in the Berggren and others (1985) time scale were developed at midlatitude (subtropical) Sites $563\left(33^{\circ} \mathrm{N}\right)$ and $558\left(38^{\circ} \mathrm{N}\right)$ (Miller and others, 1985) and portions of the middle Miocene magnetostratigraphic record at these sites are uncertain. Subsequent magnetobiostratigraphic correlations have been derived primarily from higher-latitude sites (for example, Site $608,43^{\circ} \mathrm{N}$; Miller and others, 1991, and Gartner, 1991; Site 748, Berggren, 1992) or have suffered from inadequate magnetostratigraphy (Site 588; Barton and Bloemendal, 1986; see below for discussion). Magnetostratigraphic records at tropical Ocean Drilling Program (ODP) locations (for example, Legs 108, 115, and 130) have been poor (Ruddiman, Sarnthein, and others, 1989; Duncan, Backman, and others, 1990; Kroenke, Berger, and others, 1993). ${ }^{1}$ Therefore, we sought a tropical outcrop section for magnetobiostratigraphic studies because meaningful polarity histories cannot be determined from most lowlatitude cores, which are usually unoriented in the azimuthal plane.

\footnotetext{
${ }^{1}$ The exception to this appears to be eastern equatorial Pacific ODP Leg 138, which obtained excellent upper middle to lower upper Miocene magnetostratigraphic and nannoplankton records (D. Schneider, unpub. data; D. Rio, unpub. data), although initial planktonic foraminiferal biostratigraphic results are discouraging due to intense dissolution (E. Vincent, 1992, personal commun.).
} 


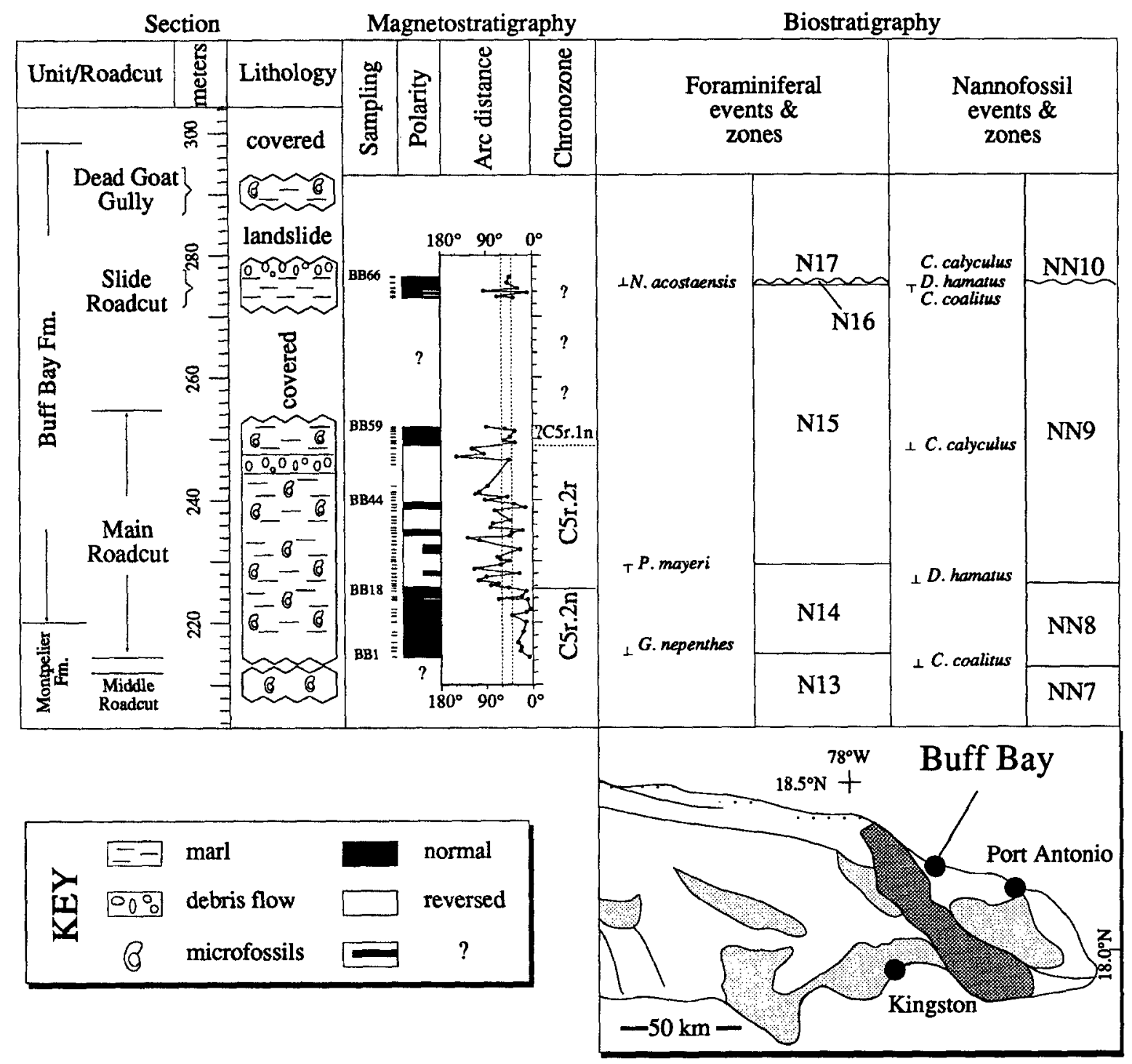

Figure 2. Thickness, measured stratigraphic section and lithostratigraphy (after C. Stuart, unpub. data), samples (BB1-BB64), magnetostratigraphy (given as arc distance; see text), polarity interpretation (black = normal; white $=$ reversed; half-column black = uncertain normal; half-column white = uncertain reversed), magnetochronozonal correlations, planktonic foraminiferal biostratigraphy (after Berggren, 1993), and nannoplankton biostratigraphy (after Aubry, 1993). Inset map shows location of Buff Bay section in northeast Jamaica (white area = middle Eocene to Miocene limestones and marls; dark stipple = lower Eocene Wagwater belt; light stipple $=$ upper Cretaceous limestones).

\section{The Buff Bay Section and the} Jamaican Conundrum

In 1987, a joint field excursion from Unocal (G. Jones, R. C. Tjalsma, and C. Stuart), Woods Hole Oceanographic Institution (W. A. Berggren), University of Lyon (M.-P. Aubry), and Lamont-Doherty Earth Observatory (D. V. Kent, K. G. Miller, M. Van Fossen) sampled sections exposed by roadcuts near Buff Bay, Jamaica (Fig. 2). Previous studies reported on planktonic foraminiferal (Berggren, 1993), nannofossil
(Aubry, 1993), and benthic foraminiferal (Katz and Miller, 1.993) results. Roadcuts at Buff Bay exposed six sections sampled by the joint field party in 1987: Lower (Pots and Pans), Middle, Main, Slide, Dead Goat Gully, and West (Fig. 2). The Lower and West sections proved to be unsuitable for isotopic and magnetostratigraphic studies and are not discussed here.

The Middle section (Fig. 2) represents the upper Spring Garden Member of the Montpelier Formation as defined by Robinson (1969). The Main, Slide, and Dead Goat
Gully roadcuts represent the Buff Bay Formation as originally defined by Robinson (1969). The general lithologies were similar to those described previously (Robinson, 1969), although closer examination of the lithology of the Main section resulted in the relocation of the formational boundary by the field party. The Spring Garden Member is a pure, white indurated chalk with characteristic black lichen overgrowths. In contrast, the Buff Bay Formation is a sandier, yellow-tan carbonate sediment that is only moderately indurated and lacks lichens. Ex- 


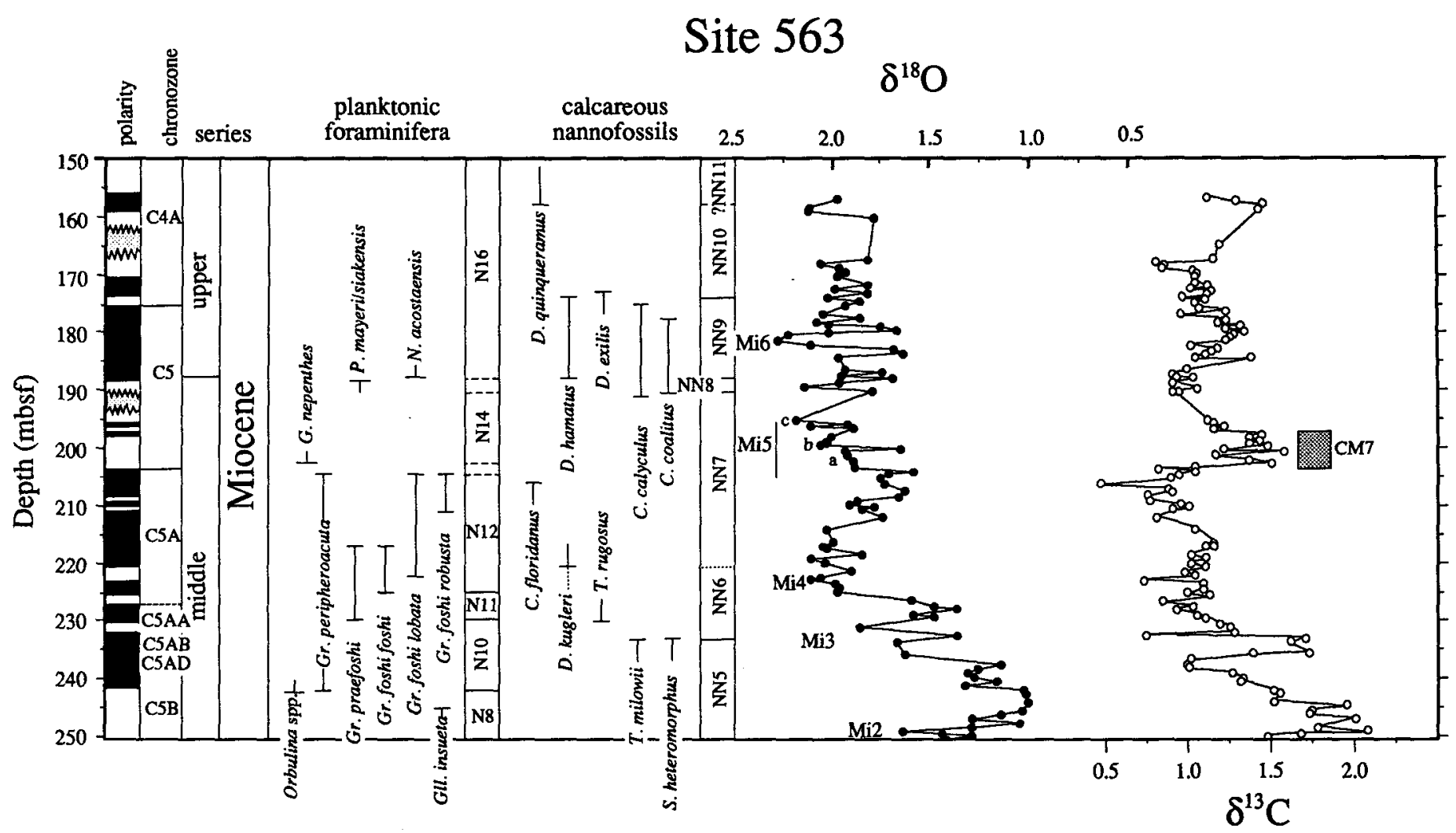

Figure 3. Site 563 isotopic stratigraphy and biostratigraphy. Modified after Wright and others (1992) using biostratigraphic data from Miller and others (1985). Letters a, b, and $c$ are informal subdivisions of Miocene oxygen isotopic zone Mi5 used here. $\mathrm{CM} 7=$ carbon maximum 7 of Woodruff and Savin (1991).

posure of the unweathered Buff Bay Formation shows it to be slightly bluish, while the Spring Garden Member is consistently white. The contact between the underlying Spring Garden Formation and the Buff Bay Formation is gradational, and the field party drew the formational boundary in the lower one-third of the Main section (Fig. 2). There are coarse sandy layers in the Main and Slide sections. The very coarse sand and larger fraction $(>1 \mathrm{~mm})$ is composed mostly of transported Amphistegina spp., Asterigerina spp., and reefal fragments (Katz and Miller, 1993). Analysis of in situ, depthdiagnostic benthic foraminiferal species indicates that the paleodepths were 1300 $2000 \mathrm{~m}$ during deposition of the Spring Garden Member and the Buff Bay Formation; the mixture of cosmopolitan and endemic benthic foraminifera indicates that this basin communicated freely with the Atlantic, although there were differences in deepwater characteristics (Katz and Miller, 1993).

Miocene-Pliocene biostratigraphic relationships among planktonic foraminifera and calcareous nannofossils of stratigraphic sections sampled near Buff Bay, Jamaica (Aubry, 1993; Berggren, 1993), differ from previously published studies (for example, Blow, 1969; Miller and others, 1985). In particular, late middle to early late Miocene biostratigraphic relationships observed at the tropical Buff Bay location are strikingly different from those observed at subtropical North Atlantic Sites 563 and 558 (Miller and others, 1985). There are global implications to the differences because these North Atlantic sites were used to calibrate biozones to the GPTS (Berggren and others, 1985).

At Buff Bay, planktonic foraminiferal Zone N14 is relatively thin (there is only a 14 m overlap of the nominate taxa Globigerina nepenthes and Paragloborotalia mayeri) compared with Zone N15 (>45 m; Fig. 2; Berggren, 1993). At Sites 563 and 558, Zone N14 yields a similar thickness as at Buff Bay despite much lower sedimentation rates (10-15 m/m.y. vs. $40 \mathrm{~m} / \mathrm{m} . \mathrm{y}$. based on Aubry, 1993); in addition, both Zones N13 and N15 are virtually absent from Sites 563 and 558 (Fig. 3; Miller and others, 1985). Nannofossil-foraminiferal biostratigraphic relationships also differ between Buff Bay and the subtropics. Zone NN9 (= total range of Discoaster hamatus) spans Zone N15 and uppermost Zone N14 at Buff Bay (Fig. 2; Aubry, 1993), a situation also reported from the Pacific (Keller and others, 1982). Conversely, Zone NN9 is associated with Zone N16 (from the first occurrence [FO] of Neogloboquadrina acostaensis to the FO of Globorotalia plesiotumida) at Sites 563 and 558 (Fig. 3; Miller and others, 1985). Zone NN8 (from the FO of Catinaster coalitus to the FO of D. hamatus) is associated with most of Zone N14 and Zone N13 partim at Buff Bay, but with uppermost Zone N14 at Site 563 (Figs. 2 and 3; Aubry, 1993; Miller and others, 1985).

These differences between tropical Jamaican (lat. $18^{\circ} \mathrm{N}$ ) and subtropical North Atlantic zonations are not due to stratigraphic peculiarities of the Buff Bay section. As we illustrate below, biostratigraphic relationships between planktonic foraminifera and nannofossils are the same at tropical Sites 289 (Ontong-Java Plateau; Shafik, 1975; Srinivasan and Kennett, 1981) and 62.1 (Bronnimann and Resig, 1971; Martini and Worsley, 1971) as they are at Buff Bay. 


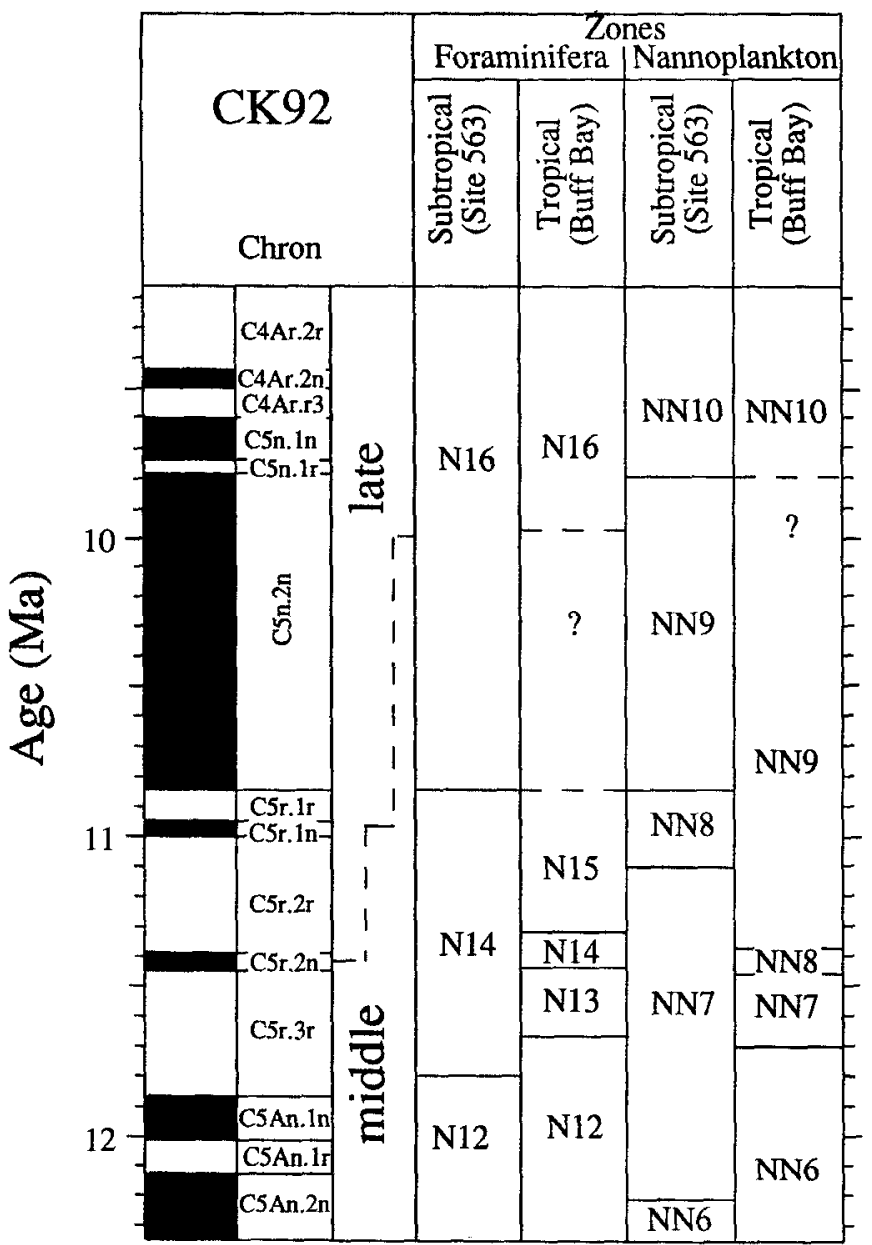

Figure 4. Revised late middle to early late Miocene time scale showing the geomagnetic polarity time scale of Cande and Kent (1992), ages of subtropical zones developed at Site 563 (Table B), and tropical zones developed using Buff Bay calibrations. The middle/late Miocene boundary is placed within Zone NN8 immediately before the FO of $N$. acostaensis (= base of Zone N16). The placement of the hase of tropical Zone N16 is uncertain and is higher than subtropical Zone N16 based on relationships at Site 289.

The differences between tropical and subtropical biostratigraphy can be explained either by diachrony or unconformities in the sections. Both foraminiferal and nannofossil ranges could be diachronous. This potential diachrony is illustrated using the time scale of Cande and Kent (1992) (referred to as CK92; Fig. 4) and correlations developed below (see Discussion); note that Figure 4 contains elements of the various time scales shown in Figure 1 (for example, the tropical zonal relationships are similar to BKD85 [Barron and others, 1985], and the subtropical relationships are those of BKV85 [Berggren and others, 1985]).

In contrast to diachrony, Aubry (1993) attributed a large part of the differences between biozones at Buff Bay and those at Site
563 and 558 to previously undetected unconformities at the subtropical sections. She suggested that a hiatus of $0.5-1.0$ m.y. occurred at the subtropical sites (that is, from ca. 11.5 to $10.8 \mathrm{Ma}$ on Fig. 4 ; see Discussion). This is not a regional or even circumAtlantic problem, because there are many sites that recorded a "Site 563 type" biostratigraphic pattern (for example, Cape Basin Site 360, Wright and others, 1992; North Atlantic Site 608, Miller and others, 1991; Gartner, 1991) and others that recorded a "Buff Bay type" pattern (for example, western equatorial Pacific Sites 289 and 62.1; Bronnimann and Resig, 1971; Martini and Worsley, 1971; Srinivasan and Kennett, 1981; Shafik, 1975; see figure on p. 82 in Winterer and others, 1971, for comparison of Site 62.1 zonations). If Aubry's (1993) suggestion is correct, then current time scales are wrong and widespread unconformities formed at about $11 \mathrm{Ma}$ (using CK92; Fig. 4). If the zones are diachronous, then the relationships shown on previous time scales (for example, Berggren and others, 1985) must be reconsidered (for example, Fig. 4). To resolve this problem, an independent means of evaluating biostratigraphic correlations is required. As a first step, we generated a magnetostratigraphic record for the Buff Bay section.

Comparison of the magnetostratigraphy and biostratigraphy of the Buff Bay section complicate the problem further. Nannofossil Zone NN9 is associated with a thick reversed magnetozone at Buff Bay (Fig. 2), whereas it is associated with a thick normal magnetozone at Sites 563 (Fig. 3) and 558. Zone NN8 is associated with a normal magnetozone at Buff Bay, but with a predominantly reversed interval at Site 563 (Fig. 3). These complications suggest that an independent evaluation of the magnetobiostratigraphy is needed. In this paper, we present the oxygen and carbon isotopic data as an independent means of evaluating magnetostratigraphic and biostratigraphic correlations.

\section{METHODS}

\section{Magnetostratigraphy}

A total of 68 oriented hand samples were taken from the Buff Bay Main and Slide sections for demagnetization experiments and magnetostratigraphic analysis; additional samples were obtained from the Middle and Pots and Pans sections that compose the bulk of the Spring Garden Member of the Montpelier Formation (Fig. 2). Two $10 \mathrm{~cm}^{3}$ specimens were cut from each hand sample for alternating field (AF) and thermal demagnetization and measurement in an ScT cryogenic magnetometer. The natural remanent magnetization (NRM) intensities are low (median values $1.79 \mathrm{~mA} / \mathrm{M}$ for the Main and Slide sections); samples from most of the Spring Garden Member (Middle and Pots and Pans sections) were very weakly magnetized (median values $0.03 \mathrm{~mA} / \mathrm{M}$ ), with intensities approaching the sensitivity of the magnetometer, and were not considered further. NRMs were found to be entirely of normal polarity with a mean direction in in situ coordinates of $353.1^{\circ} / 29.2^{\circ}$ (declination/inclination), very close to the dipole field direction in northeast Jamaica 


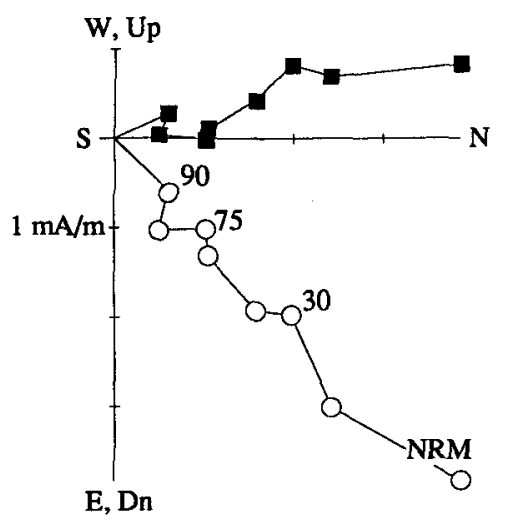

BB35.1 [in situ coordinates]

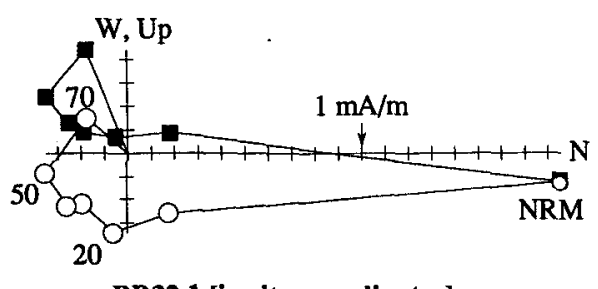

BB32.1 [in situ coordinates]

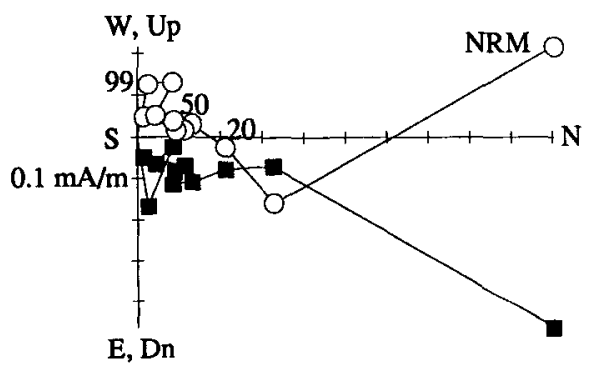

BB48.2 [in situ coordinates]

Figure 5. Representative demagnetograms from the Buff Bay section (open/closed symbols show vertical/horizontal projection of vector endpoints, demagnetization in units of millitesla). Top, an example of a normal polarity magnetization, or, alternatively, a complete remagnetization in a recent field. In this case the magnetization migrates very little and decays toward the origin during demagnetization. Center, an example of an overprinted reversed polarity magnetization in which the magnetization vector migrates $105^{\circ}$ into the southern (and upper) hemisphere. Bottom, a less clearly defined reversed polarity magnetization in which the magnetization vector migrates $<90^{\circ}$ toward the southern hemisphere. $\left(0.0^{\circ} / 33.5^{\circ}\right)$. A tentative interpretation of these data is that the magnetic polarity of the samples is predominantly normal and/or the NRM has been severely affected by a recent remagnetization.

The Buff Bay samples were subjected to progressive $\mathrm{AF}$ demagnetization to peak fields up to $100 \mathrm{mT}$ in steps ranging from 5 to $10 \mathrm{mT}$ (Fig. 5). Roughly half of the magnetizations decayed along an origin-bound trajectory from the typical NRM direction (north/down) while the remainder decayed and then increased in magnetization intensity in the southern hemisphere (south/up or south/down). AF demagnetization at steps as high as $70-100 \mathrm{mT}$ were not capable of fully resolving this magnetization from the NRM but indicate the presence in some samples of a high-coercivity reversed polarity magnetization heavily overprinted by a lower-coercivity secondary magnetization. Attempts at thermal demagnetization of a pilot suite of samples generally revealed less-stable demagnetization profiles and were similarly incapable of resolving the component of reversed magnetization.

For the purposes of Miocene magnetic polarity stratigraphy, using demagnetization profiles, we can identify a subset of Buff Bay samples that contain the reversed polarity magnetization (albeit incompletely resolved from a strong normal polarity overprint). The reversed polarity samples are those in which during AF demagnetization, the total magnetization vector migrates over relatively large arc distances from the northern to southern hemisphere (Fig. 5). A problem emerges when judging the polarity of the remaining samples that demagnetized along origin-bound trajectories. The presence of a strong normal polarity overprint makes it difficult to distinguish a truly Miocene normal polarity magnetization from an original, Miocene reversed magnetization now fully remagnetized by the recent overprint. Furthermore, given the proximity of North American Miocene poles to the spin axis $\left(88^{\circ} \mathrm{N}, 100^{\circ} \mathrm{E}\right.$; Irving and Irving, 1982$)$ and the shallow tilt of bedding at Buff Bay $\left(17^{\circ}\right.$ west), we can expect a maximum angular separation between a Miocene normal polarity magnetization and a recent overprint to be just $9^{\circ}$.

Determining a polarity history for the Buff Bay sections is not straightforward. The data do not allow us to identify a Miocene normal polarity magnetization with full confidence and standard methods. However, we applied a quantitative, albeit unconventional, means of evaluating our polarity de- terminations. The demagnetization data for each sample were subjected to principal component analysis (Kirschvink, 1980), which determines a least-squares-fit vector and the mean angular deviation (MAD value) from a least-squares vector (Table $\mathrm{A}^{2}$ ). A MAD value of about $20^{\circ}$ was selected as a cutoff for data quality leaving 63 samples for polarity determination. Next, for each sample we measured the total arc distance traversed by the magnetization vector during $\mathrm{AF}$ demagnetization from $10 \mathrm{mT}$ to the final demagnetization step (Table A). In the case of a clearly reversed Buff Bay demagnetization profile, the magnetization vector is expected to traverse into the southern hemisphere over large arc distances (potentially up to $180^{\circ}$, Fig. 5), whereas other samples that are normal or fully overprinted are expected to traverse very little during demagnetization (potentially $0^{\circ}$ but more likely ranging between $0^{\circ}$ and $\sim 30^{\circ}$ ).

Arc distance data and visual inspection of demagnetization profiles were used to construct magnetic polarity stratigraphy (Fig. 2); Table A). At the bottom of the Main section the arc distance values are relatively low $\left(0^{\circ}-40^{\circ}\right)$, suggesting a normal polarity interval from $213-225 \mathrm{~m}$. Arc distances are generally higher than $60^{\circ}$ in the upper part of the Main section (225-251 m), suggesting a predominantly reversed polarity zone with thin normal polarity zones. The Slide section $(273-275 \mathrm{~m})$ is predominantly normal in polarity based on the low arc distances. Intermediate arc distance data (between about $40^{\circ}$ and $60^{\circ}$ ) were not used to define a change in polarity, and single-sample zonations were left as indeterminable (black or white notches in Fig. 2).

We conclude that the magnetostratigraphy of the Buff Bay section is tentative. The identification of a moderately thick reversed magnetozone in much of the Main section (Fig. 1) most likely represents a reversed field, although we cannot say for certain if the normal magnetozones identified are representative of the past field or a modern overprint.

\section{Isotopic Stratigraphy}

We analyzed samples from the Buff Bay Middle, Main, and Slide sections for stable

${ }^{2}$ GSA Data Repository item 9449 , Table A (stable isotopic data) and Table B (magnetostratigraphy and demagnetization data), is available on request from Documents Secretary, GSA, P.O. Box 9140, Boulder, CO 80301. 
TABLE 1. AGE ESTIMATES OF TAXA USED IN BUFF BAY, JAMAICA, AGE-DEPTH DIAGRAM

\begin{tabular}{|c|c|c|}
\hline Taxon & $\begin{array}{l}\text { Age } \\
\text { (Mia) }\end{array}$ & Comment \\
\hline \multicolumn{3}{|l|}{ Nannofossils } \\
\hline $\begin{array}{l}\text { LO Discoaster hamatus } \\
\text { LO Catinaster calycultus } \\
\text { FO Discoaster hamatus } \\
\text { FO Cutinaster coalitus } \\
\text { FO Discoaster kuglen } \\
\text { FO Triquetrorhabdulus rugosus } \\
\text { LO Sphenolithus heteromorphus } \\
\text { LO H. umpliaperta }\end{array}$ & $\begin{array}{r}9.78 \\
9.59 \\
10.83 \\
11.11 \\
12.20 \\
13.09 \\
13.26 \\
16.04\end{array}$ & 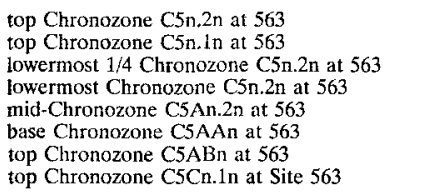 \\
\hline \multicolumn{3}{|l|}{ Planktonic foraminifera } \\
\hline $\begin{array}{l}\text { FO Neogloboquadrina acostaensis } \\
\text { LO Paragloborotalia mayeri } \\
\text { FO Glabigerina nepenthes } \\
\text { LO Globorotalia fohsi rohusta } \\
\text { LO Globorotalia fohsi Iobata } \\
\text { FO Globorotalia fohsi robusta } \\
\text { FO Globoroula fohsi lobata } \\
\text { FO Orbulina spp. }\end{array}$ & $\begin{array}{l}10.83 \\
10.80 \\
11.80 \\
11.90 \\
11.90 \\
12.10 \\
12.60 \\
15.10\end{array}$ & $\begin{array}{l}\text { lowermost } 1 / 4 \text { Chronozone C5n.2n at } 563 \\
\text { near base Chronozone C5n.2n at } 563 \\
\text { near base Chronozonc C5r.3r at } 563 \\
\text { top Chronozone C5an. In at } 563 \\
\text { top Chronozone C5an. } 1 \mathrm{n} \text { at } 563 \\
\text { base Chronozone C5an. } 1 \mathrm{r} \text { at } 563 \\
\text { uppermost Chronozone C5an at } 563 \\
\text { lower Chronozone C } 5 \text { Br.n at } 563\end{array}$ \\
\hline \multicolumn{3}{|l|}{ Magnetochrons and isotopes } \\
\hline $\begin{array}{l}\text { top Chronozone C5r.1r } \\
\text { alternate top Chronozone C5r.2r } \\
\text { top Chronozone C5r.2n } \\
\text { base Chronozone C5r.2n } \\
\text { alternate carbon level } 1 \\
\text { carbon level } 1\end{array}$ & $\begin{array}{l}10.834 \\
10.989 \\
11.378 \\
11.434 \\
12.333 \\
12.000\end{array}$ & $\begin{array}{l}275 \mathrm{~m} \\
275 \mathrm{~m} \\
225 \mathrm{~m} \\
213 \mathrm{~m} \\
163 \mathrm{~m} \text { base of Chronozone C5an.2 at Site } 563 \\
163 \mathrm{~m} \text { base of Chronozone C5an.1 at Site } 563\end{array}$ \\
\hline \multicolumn{3}{|c|}{ Ages of isotope changes not shown on Figure 7: } \\
\hline $\begin{array}{l}\text { carbon level } 4 \\
\text { carbon lovel } 3 \\
\text { carbon lcvel } 2\end{array}$ & $\begin{array}{l}11.3 \\
11.5 \\
11.7\end{array}$ & \\
\hline
\end{tabular}

*See Figure 7; calibrated to the GPTS of Cande and Kent, 1992. oxygen and carbon isotopes (Fig. 6). The lower part of the Montpelier Formation (Pots and Pans section) was heavily indurated and not analyzed. The Main and Slide sections are friable and not well indurated, and preservation of foraminifera is good to excellent. The Middle section is more indurated, although foraminifera are generally moderately to well preserved. The wellpreserved nature of the benthic foraminifera is illustrated by Katz and Miller (1993), and on the basis of the state of preservation (for example, with generally clear pores, lack of crystal overgrowths), we suggest that the isotopic values are not significantly altered by diagenesis.

Samples were washed with tap water and dried, and the $>150-\mu \mathrm{m}$ size fraction was picked for mixed Cibicidoides spp. (primarily C. wuellerstorfi). These benthic foraminifera were ultrasonically cleaned for 5-10 s and then roasted at $370^{\circ} \mathrm{C}$ in a vacuum. Oxygen and carbon isotopic measurements were made at Lamont-Doherty Earth Observatory using a Carousel-48 automatic carbonate preparation device attached to a

\section{Buff Bay, Jamaica}

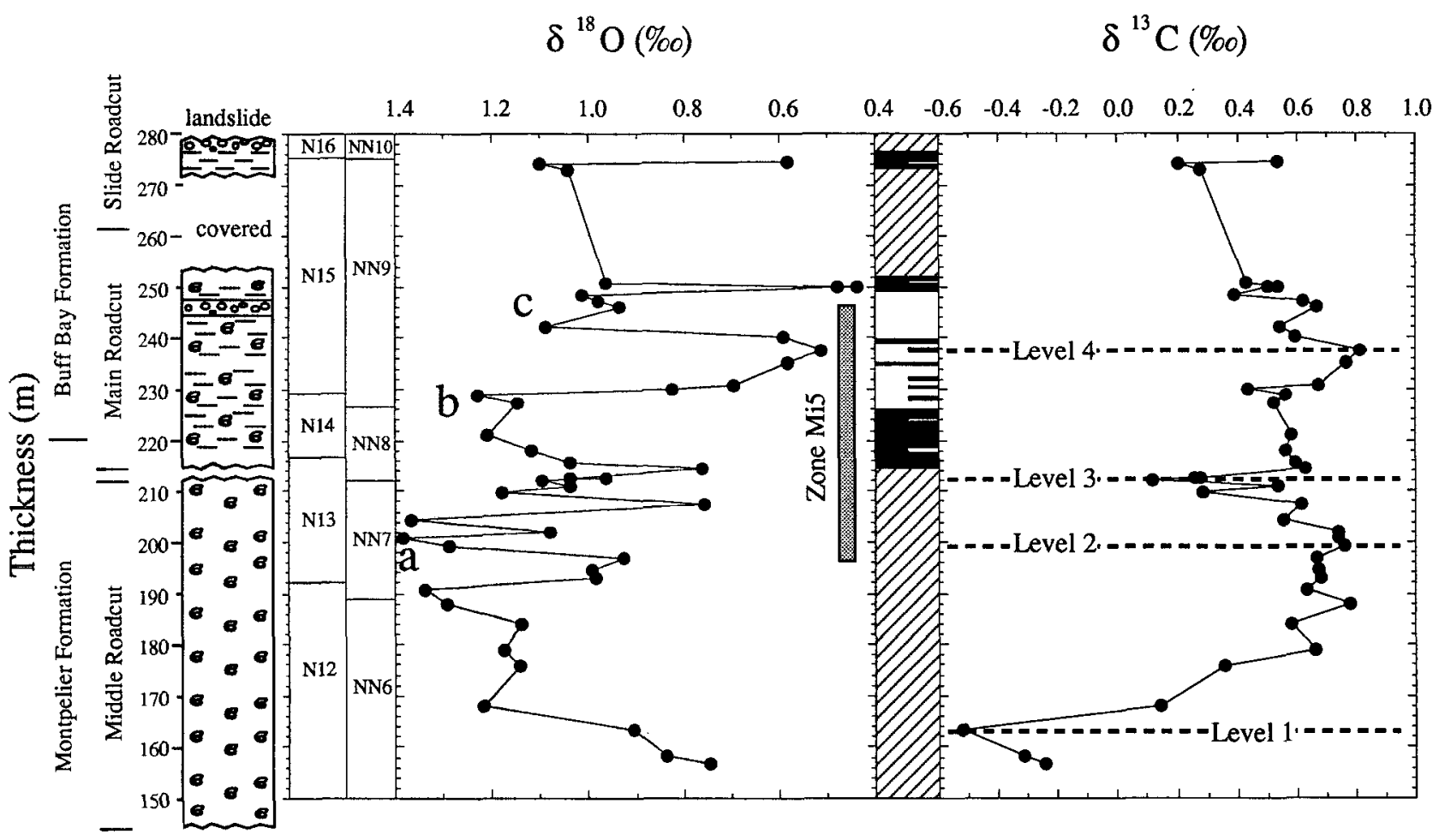

Figure 6. Oxygen and carbon isotopic stratigraphy of the Main and Slide sections showing the polarity and magnetochronozones from Figure 2, the foraminiferal biostratigraphy of Berggren (1993), and the nannofossil biostratigraphy of Aubry (1993). Letters a, b, and c are informal subdivisions of Miocene oxygen isotopic zone Mi5 used here. 
Finnigan MAT 251 mass spectrometer. Analytical error based on 20 NBS-19 measurements made during the analysis of stable isotopic data from Buff Bay was $0.05 \%$ and $0.02 \%$ for $\delta^{18} \mathrm{O}$ and $\delta^{13} \mathrm{C}$, respectively. The data are reported in values referenced to the PDB (Peedee belemnite) standard (Table B).

Wright and Miller (1992) outlined applications of stable isotopic stratigraphy to the Miocene and identified the oxygen isotopic zones applied here. Isotopic studies of Miocene sections are still fairly coarse (for example, typically 50 k.y. sampling intervals) compared to late Neogene studies (for example, typically 1-5 k.y. sampling intervals), which resolve "Milankovitch" scale astronomical periodicities $(20,40,100 \mathrm{k} . y$.). Although such astronomical periodicities are embedded in the Miocene record (for example, Pisias and others, 1985), longer period changes (m.y. scale) are observed and may be correlated from site to site (Miller and others, 1991b; Woodruff and Savin, 1991; Wright and Miller, 1992).

\section{RESULTS}

\section{Magnetostratigraphy}

Planktonic foraminifera and calcareous nannoplankton indicate a general assignment of the Main and Slide sections to the upper middle to lower upper Miocene. Within this framework, the thick reversed polarity zone observed in the Main Section ( $\sim 225-251 \mathrm{~m}$, Fig. 2) is interpreted as Chronozone C5r partim. This correlation is independent of the isotopic stratigraphy presented below, although the interpretation of the position within Chronozone C5r is ambiguous without the isotopic stratigraphy. We are confident that this predominantly reversed zone represents a reversed magnetic field polarity; however, thin "normal" intervals within the reversed section cannot be distinguished from complete overprinting by the present-day field.

The moderately thick normal magnetozone from 213-225 m could be correlated with either Chronozone C5An or Chronozone C5r.2n (a normal polarity event within Chronozone C5r; Cande and Kent, 1992), or it may represent a complete overprinting by the present-day field. The presence of two reversely magnetized samples at $218.1 \mathrm{~m}$ and $223.9 \mathrm{~m}$ (Fig. 2) suggests that at least some intervals within this normal polarity zone escaped complete remagnetization. On the basis of the isotopic correlations, we correlate the normal polarity magnetozone to Chronozone C5r.2n.

\section{Isotopic Stratigraphy}

A distinct $\delta^{18} \mathrm{O}$ increase occurs in the Main section at about $155-190 \mathrm{~m}$, with peak values attained at three levels: $201 \mathrm{~m}, 228 \mathrm{~m}$, and $242 \mathrm{~m}$ (Fig. 6). Benthic foraminifera at Buff Bay record global $\delta^{18} \mathrm{O}$ changes recognized at open-ocean sites (Miller and others, 1991a; Wright and Miller, 1992), although the values are offset from these sites by $\sim 1 \%$ o due to warmer bottom-water temperatures. Based on its general biostratigraphic position, the increase in the Main section cannot be correlated with Zone Mi4 (middle middle Miocene Zone N12; Fig. 3) or Mi6 (lower upper Miocene Zone N16; Fig. 3). Rather, this late middle Miocene $\delta^{18} \mathrm{O}$ increase is the one associated with Zone Mi5, which occurred in early Chron C5r (Figs. 3 and 6; Miller and others, 1991a; Wright and Miller, 1992). The three peaks within Zone Mi5 apparently correlate with three similar peaks at Site 563; intersite correlation of these three peaks supports the carbon isotopic correlations developed below (Figs. 7 and 8).

Identification of oxygen isotopic Zone Mi5 provides a basis for the detailed interpretation of the magnetozones at Buff Bay (Fig. 2). The Mi5 $\delta^{18} \mathrm{O}$ increase occurs just below a normal polarity magnetozone (213$225 \mathrm{~m}$ ) in a section that proved to be unsuitable for magnetostratigraphic analysis (Fig. 6). We thus correlate the normal magnetozone with Chron C5r.2n (Fig. 2); 11.43$11.38 \mathrm{Ma}$ ). Simple matching of polarity patterns might indicate that this normal polarity interval correlates with Chronozone C5 An, but this is not consistent with the isotopic correlations. On the basis of the isotopic correlations, we assign the reversed magnetozone from $225-251 \mathrm{~m}$ to Chronozone C.5r.2r (Fig. 2) with an age of 11.3811.00 Ma (Cande and Kent, 1992).

Several isotopic correlation schemes have been proposed that use carbon isotopic changes (Loutit and others, 1983; Vincent and Berger, 1985; Woodruff and Savin, 1991), and carbon isotopic changes proved to be the most useful tool in correlating the Buff Bay sections to other sites. We identify four distinct carbon isotopic excursions at Buff Bay, Jamaica (labeled 1-4 upsection on Figs. 6 and 7):

- Level 1 is a $\delta^{13} \mathrm{C}$ minimum at $163 \mathrm{~m}$ within Zones N12 and NN6.
- Level 2 is a $\delta^{13} \mathrm{C}$ maximum at $199.5 \mathrm{~m}$ within Zones N13 and NN7; this level is immediately below peak $\delta^{18} \mathrm{O}$ values associated with an oxygen isotopic maximum ("Zone Mi5a" on Fig. 6) as it is at Site 563 (Fig. 3).

- Level 3 is a $\delta^{13} \mathrm{C}$ minimum at $212 \mathrm{~m}$ within Zones N13 and NN7 immediately below normally magnetized sediments that are correlated with Chron C5r.2n.

- Level 4 is a $\delta^{13} \mathrm{C}$ maximum at $238 \mathrm{~m}$ within lower Zone N15 and lower NN9 that occurs in a reversed magnetized section correlated with Chronozone C5r.2r. This level is bracketed by two oxygen isotopic maxima ("Mi5b and 5c" on Fig. 6), as it is at Site 563 (Fig. 3).

Carbon isotope Levels 2-4 compose an interval of relatively high $\delta^{13} \mathrm{C}$ values corresponding to carbon maximum 7 (CM7 of Woodruff and Savin, 1991; Fig. 7). We note that there are several correlatable carbon and oxygen isotopic changes within this interval, allowing us to recognize Levels 2-4 at other sites.

These carbon isotopic changes can be used to correlate the Buff Bay section with tropical to high-latitude Deep Sea Drilling Project (DSDP) and ODP sites. The upper middle Miocene sections at Sites 289, 563, and Buff Bay show remarkably similar isotopic patterns, and the records at highlatitude Sites 747 and 608 record similar variations (Fig. 7). Although differences among the records can be attributed to differences in deep water sources, the similar carbon isotopic changes observed can be best interpreted as whole-ocean $\delta^{13} \mathrm{C}$ variations on the million year scale (for example, Miller and Fairbanks, 1985). The synchrony of these global changes is established by correlating among sites with good magnetostratigraphy (Sites 563, 608, 747). Once the synchrony is established, carbon isotopes provide a way to evaluate the magnetostratigraphy at Buff Bay and to correlate tropical sites to other locations.

\section{Level 1}

Level 1 is correlated with Chronozone C5An at Sites 563 and 747 (probably C5An.1, although correlation with C5An.2 is possible; Table B; Fig. 7). At Site 608, Level 1 occurs within a thin interval of uninterpreted polarity $(\sim 258 \mathrm{~m}$ below sea floor [mbsf]).

Level 1 is correlated with uppermost Zone N12 in the subtropics. At Site 563, Level 1 (206 mbsf) falls within upper Zone 


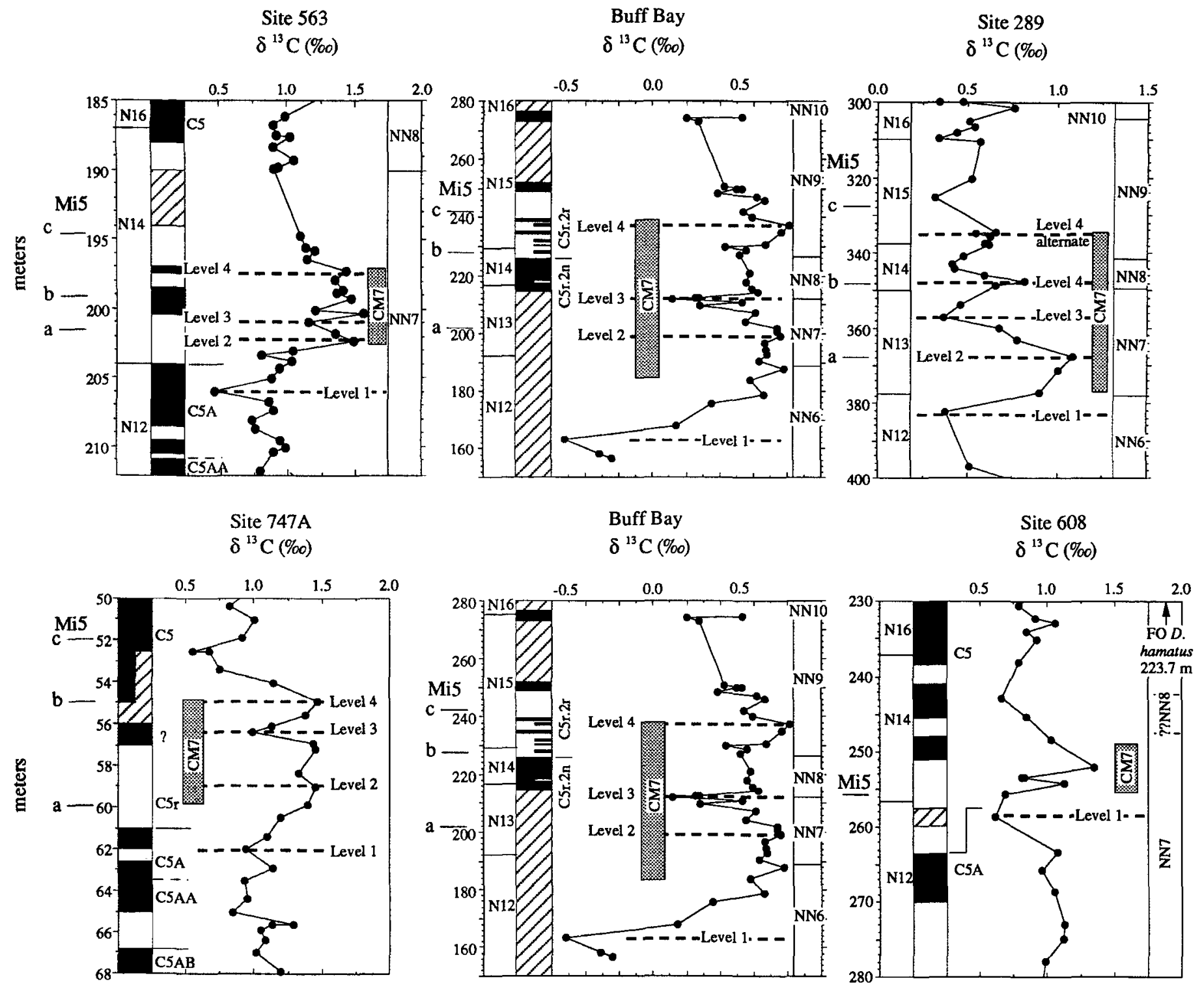

Figure 7. Comparison of carbon isotopic and biostratigraphic results from Buff Bay, Site 563 (Miller and others, 1985), Site 608 (Miller and others, 1991; Gartner, 1991), Site 747 (Wright and Miller, 1992), and Site 289 (Shafik, 1975; Srinivasan and Kennett, 1981; Woodruff and Savin, 1989). Dashed lines correlate between carbon isotope Levels 1, 2,3, and 4 noted at the sites (see text); a, b, and c are informal subdivisions of Miocene oxygen isotopic zone Mi5 used here.

$\mathrm{N} 12$ below the last occurrence (LO) of Globorotalia fohsi spp. (204 mbsf; we use the LO of $G$. fohsi ssp. as the zonal criterion for the base of Zone N13 following Kennett and Srinivasan, 1983). Only one specimen of the Globorotalia fohsi lineage was found at Site 608 , and Level 1 occurs in undifferentiated Zones N12-N13. Tropical-subtropical zonal markers are absent at high-latitude Site 747 (Berggren, 1992; Aubry, 1993); although correlations there are useful in verifying carbon isotopic changes relative to magnetostratigraphy, they shed little light on the biostratigraphic problems discussed here.
Level 1 is also correlated with Zone N12 in the tropics. At Buff Bay, Level 1 (163 m elevation) occurs within lower Zone N12, well below the LO of Globorotalia fohsi robusta at $192 \mathrm{~m}$ (Berggren, 1993). At Site 289, Level 1 is also correlated with Zone N12 (Fig. 7). The consistent occurrence of Level 1 in Zone N12 indicates no significant diachrony in the LO of the $G$. fohsi spp., the nominate criterion for the base Zone N13 of Kennett and Srinivasan (1983), although minor diachrony in the LO of Globorotalia fohsi is indicated by the variable position of Level 1 within Zone N12.
Nannofossil correlations with Level 1 differ between the tropics and higher latitude locations. Level 1 is associated with Zone NN6 at the tropical locations (Buff Bay and Site 289) and with Zone NN7 at subtropical Site 563 and high-latitude Site 608. This implies that the nominate criterion for the base of Zone NN7 (FO of $D$. kugleri) is diachronous, being delayed in the tropics.

Level 2

The position of Level 2 is clearest at Site 563 , where it is placed at $202.3 \mathrm{mbsf}$ and falls 
within a reversed polarity section above Chronozone C5An. At Site 747, it also lies within a thick reversed section above Chronozone C5An (Fig. 7). This reversed zone must represent Chronozone C5r partim between 57 and 61 mbsf, although levels above $56 \mathrm{mbsf}$ suffer from uncertain polarity and it is not clear what part of $\mathrm{C} 5 \mathrm{r}$ is represented at Site 747 (Fig. 7). At Site 608, the sampling interval is coarser than at the other sites, and Levels 2-4 cannot be discriminated.

At Site 563, Level 2 occurs in lowermost Zone N14, $4 \mathrm{~m}$ above the FO of $G$. nepenthes (204 mbsf). Although Levels 2-4 cannot be discriminated at Site 608 , the maximum of CM7 (= Levels 2-4) is in lower N14 at this site as it is at Site 563 (Fig. 7). At Buff Bay, Level 2 occurs in lower Zone N13, as it does at Site 289 (Fig. 7). This implies that the zonal marker for the base of N14 (= FO of $G$. nepenthes) was delayed at the tropical sites relative to Sites 563 and 608. Level 2 is associated with mid-Zone NN7 at Sites 289, 563, 608, and Buff Bay.

Level 2 is associated with the first of three $\delta^{18} \mathrm{O}$ maxima associated with Zone Mi5 ("Mi5c") at Sites 563 (Figs. 3 and 7), Buff Bay (Figs. 6 and 7), 289 (Woodruff and Savin, 1989; Fig. 7), and 747 (Wright and Miller, 1992; Fig. 7), supporting its synchrony among these locations.

\section{Level 3}

At Site 563, Level 3 is placed at 201 mbsf, immediately below the base of a normal maghetozone within Chronozone C5r (Fig. 7) At Buff Bay, Level 3 occurs immediately below the section interpreted for magnetostratigraphy and lies just below a normal magnetozone. Level 3 apparently occurs at 56.3 mbsf at Site 747 within an interval of normal polarity; this may be a normal magnetozone with Chronozone C5r or the base of Chronozone C5n, or it may reflect problems in the magnetostratigraphic record from about 52 to $57 \mathrm{mbsf}$.

At Buff Bay, Level 3 (212 m elevation) falls near the top of Zone N13, $5 \mathrm{~m}$ below the FO of $G$. nepenthes ( $217 \mathrm{~m}$ elevation); it also occurs within upper Zone N13 at Site 289. At Site 563, this level occurs in Zone Ni4, $4 \mathrm{~m}$ above the FO of $G$. nepenthes (204 mbsf). This again indicates that the zonal marker for the base of N14 (= FO of $G$. nepenthes) was delayed at the tropical sites relative to Site 563 .

Level 3 is associated with the middle of Zone NN7 at Site 563, upper Zone NN7 at Site 289, and the top of Zone NN7 at Buff
Bay. This implies that the nominate criterion for the base of Zone NN8 (FO of $C$. coalitus) is diachronous, being delayed in the subtropics.

This level is immediately below the second of three $\delta^{18} \mathrm{O}$ maxima associated with Zone Mi5 ("Mi5b") at Site 563 (Figs. 3 and 7), Buff Bay (Figs. 6 and 7), 289 (Woodruff and Savin, 1989; Fig. 7), and 747 (Wright and Miller, 1992; Fig. 7), supporting its synchrony among these locations.

\section{Level 4}

At Site 563, Level 4 is associated with a very thin normal magnetozone within Chronozone C5r (Fig. 7); we suspect that this thin interval may represent overprinting by the present-day field. Level 4 falls in the middle part of the reversed magnetozone correlated to Chronozone C5r at Buff Bay. At Site 747 , this level is placed within an interval of uninterpreted polarity from 52.5 to 56 mbsf. Whereas the original data by Heider and others (in Wise, Schlische, and others, 1991) suggests that Level 4 occurs within reversed polarity sediments, shorebased results placed Level 4 in normally magnetized sediments (Heider and others, 1992). Level 4 was not identified at Site 608, and its location at Site 289 is unclear because it could be placed either at 348 or 334 mbsf.

Although we have demonstrated that Levels 1-3 are synchronous among two or more locations relative to magnetostratigraphy, we cannot do this for Level 4 . Nevertheless, because Level 4 is the top of an interval of generally high carbon isotope values (= the CM7 carbon isotope maximum of Woodruff and Savin, 1991), it is a recognizable and correlatable point in both the Buff Bay and Site 563 sections. In addition, this level immediately underlies the third of three $\delta^{18} \mathrm{O}$ maxima associated with Zone Mi5 ("Mi5b") at Sites 563 (Figs. 3 and 7), Buff Bay (Figs. 6 and 7), 289 (Woodruff and Savin, 1989; Fig. 7), and 747 (Wright and Miller, 1992; Fig. 7), again indicating that it is synchronous among locations.

Level 4 is placed in lower Zone N15 at Buff Bay. At Site 289, Level 4 is also found either in Zone N15 or N14, depending on its placement. At Sites 563 and 608, the LO of $P$. mayeri and the FO of $N$. acostaensis are juxtaposed, indicating that Zone N15 is not represented at these sites or that it lies between samples. At Site 563, Level 4 is placed in mid-Zone N14 at 197.5 mbsf (10.5 $\mathrm{m}$ below the FO of $N$. acostaensis). This indicates that the nominate criterion for the base of Zone N15 (LO of $P$. mayeri) was premature at tropical locations (that is, Zone N15 is only valid at tropical locations). Level 4 is found in lower Zone NN9 at Buff Bay, whereas it is found in Zone NN7 at Site 563. This implies that Zone NN9 partim in the tropics correlates with Zone NN7 partim in the subtropics (for example, Fig. 4) and that there is considerable diachrony in the range of the nominate taxon for Zone NN9, D. hamatus. At Site 289, Level 4 may be either in Zone NN8 or NN9, depending on its placement (Fig. 7).

\section{DISCUSSION}

\section{Comparisons with Site 588}

Site 588, located in the western subtropical Pacific $\left(26^{\circ} \mathrm{S}\right)$, is widely used as a Miocene reference section because of its excellent oxygen, carbon, and strontium isotopic records (Kennett, 1986; Woodruff and Savin, 1991; Flower and Kennett, 1993; Hodell and Woodruff, 1994). However, the magnetostratigraphy for Hole 588A (that is, below $\sim 235 \mathrm{mbsf}$ ) is entirely based on NRM data (Barton and Bloemendal, 1986) and is therefore suspected of overprinting by the present-day field (Fig. 9). In addition, foraminiferal relationships show several anomalies, such as the range of $P$. mayeri until the end of Chron C5n (1-2 m.y younger than found at any other sites) (Jenkins and Srinivasan, 1986) (Fig. 9). The LO of $N$. acostaensis is significantly delayed (that is, it occurs in uppermost Zone NN9) relative to the subtropical Atlantic, as previously observed at other Pacific locations (Keller and others, 1982) (Fig. 9). Nannofossil data appear more consistent, and the stable isotopic record presented by Kennett (1986) allows us to recognize the same carbon isotopic levels at this site: Level 1 occurs in the upper part of Zone NN6 as it does in the tropical Pacific sites; however, Levels 2-4 occur in Zone NN7, as they do at other subtropical sites (Fig. 9). Oxygen isotopic correlations of Zone Mi5a-c are consistent with the carbon isotopic correlations (Fig. 9). These isotopic correlations contradict the interpretation of a reversed magnetozone between 241 and $252 \mathrm{mbsf}$ as Chron C5Ar (Barton and Bloemendal, 1986). If this reversed magnetozone represents the past field, then it should correlate with Chron C5r (Fig. 9); however, we place little credence in the interpretation of the NRM data at Hole 588A. 


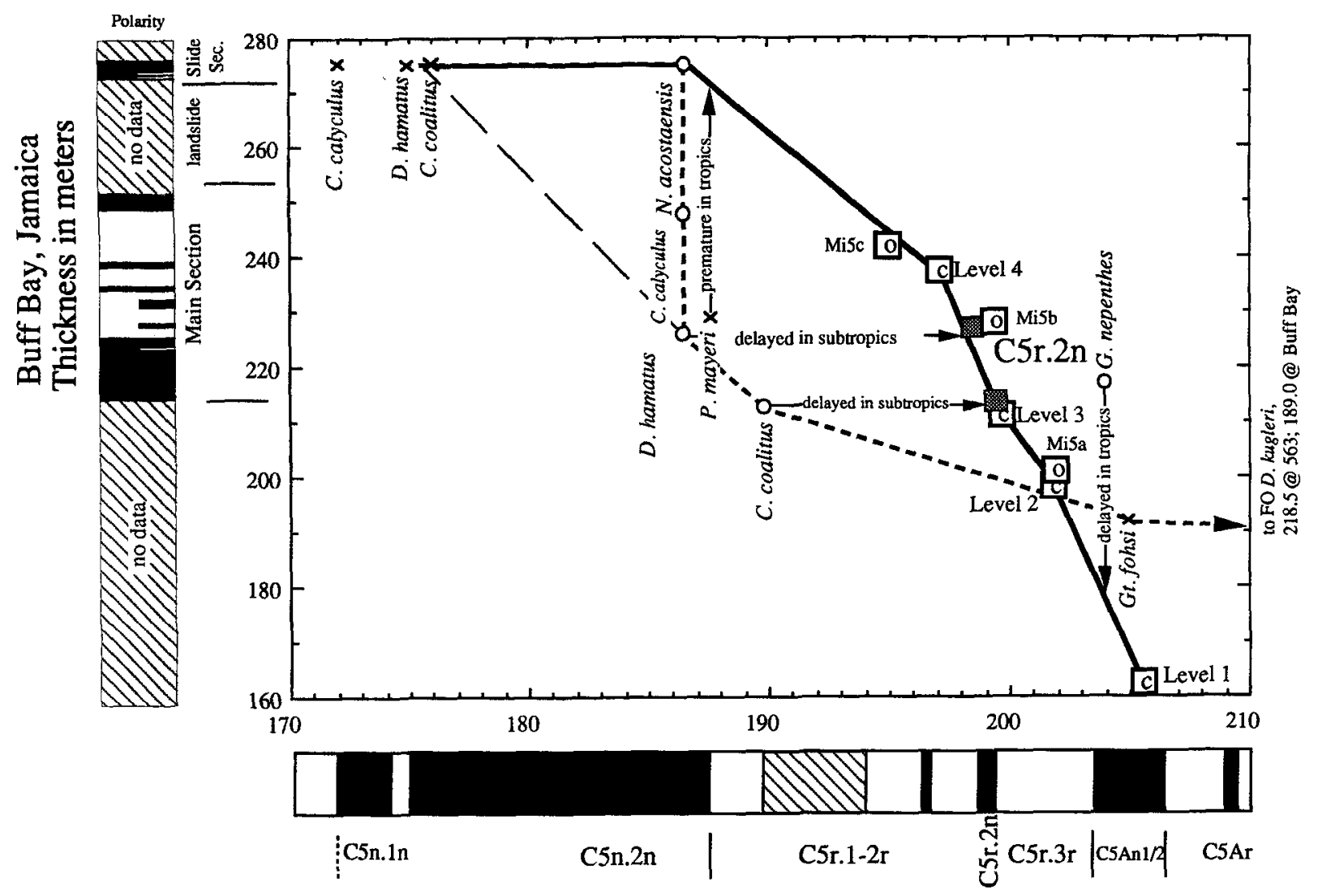

Site 563, Depth mbsf

Figure 8. Depth-depth plot of Buff Bay, Jamaica, and Site 563, showing polarity interpretation, possible chronozonal correlations (for example, C5r, etc.), first occurrences of taxa (open circles) and last occurrences ( $x$ 's). Three tentative lines of correlation are shown. The first (hypothesis I; wide dashes, thin line) requires that reversed magnetized sediments at Buff Bay correlate with normally magnetized sediments at Site 563; we regard this as unlikely. The second (hypothesis II; short dashes) requires mutually exclusive unconformities in Jamaica and Site 563; however, this also requires that apparently normally magnetized sediments in Jamaica correlate with reversed magnetized sediments at Site 563, perhaps due to normal overprinting in Jamaica. The third (hypothesis III, solid lines) requires diachronous first and last occurrences of five taxa. Stable isotopic correlations ( $c=$ carbon; $0=0 x y g e n$ ) indicate that the third correlation is correct and diachrony is illustrated (arrows).

\section{The Jamaican Conundrum}

The fundamental problem posed by the Jamaican conundrum is that foraminiferal and nannofossil biostratigraphic zonations are remarkably different at subtropical (Sites 563 and 558) and tropical locations (Buff Bay, Site 62.1 [see figure on p. 82 in Winterer and others, 1971], and Site 289 [Figs. 7 and 10]). We approached this intriguing problem with three working hypotheses, all of which require some latitudinal diachrony of taxonomic ranges. In order to formulate these hypotheses, we compared biostratigraphic, magnetostratigraphic, and isotopic levels at Site 563 with those at Buff Bay using a depth-depth diagram (Fig. 8). This depth-depth diagram shows three possible hypotheses that reconcile the tropical and subtropical records.

Hypothesis I. D. hamatus first occurs and $P$. mayeri last occurs near the base of a thick reversed interval at Buff Bay but at the base of a thick normal interval at Site 563. If we reject the magnetostratigraphy at either Site 563 or Buff Bay, then the biostratigraphic ranges can be partly reconciled (long dashed lines, Fig. 8). This hypothesis requires that the FOs of $N$. acostaensis (see also Keller and others, 1982, for an example of delayed FO of this taxon) and $G$. nepenthes were delayed in the tropics. As stated above, we believe that the thick reversed interval at Buff Bay represents a field reversal, and we find no reason to reject the magnetostratigraphy at either location.
Hypothesis II. If a previously undetected unconformity is placed at Site 563 near the base of the thick normal interval (thick dashed line, Fig. 8), and an unconformity is placed at $272 \mathrm{~m}$ at Buff Bay (Aubry, 1993), then most of the relative diachrony can be eliminated. This is the interpretation proposed by Aubry (1993), and it has the following implications (Fig. 8).

(1) Reversely magnetized sediments at Site 563 would correlate with normally magnetized sediments at Buff Bay. We place much less credence in the normal magnetozone at the base of the Main Section at Buff Bay, and magnetostratigraphy cannot be used to refute this hypothesis.

(2) Diachrony is greatly reduced but not eliminated because the FO of $G$. nepenthes is still delayed at Buff Bay (Fig. 8). 


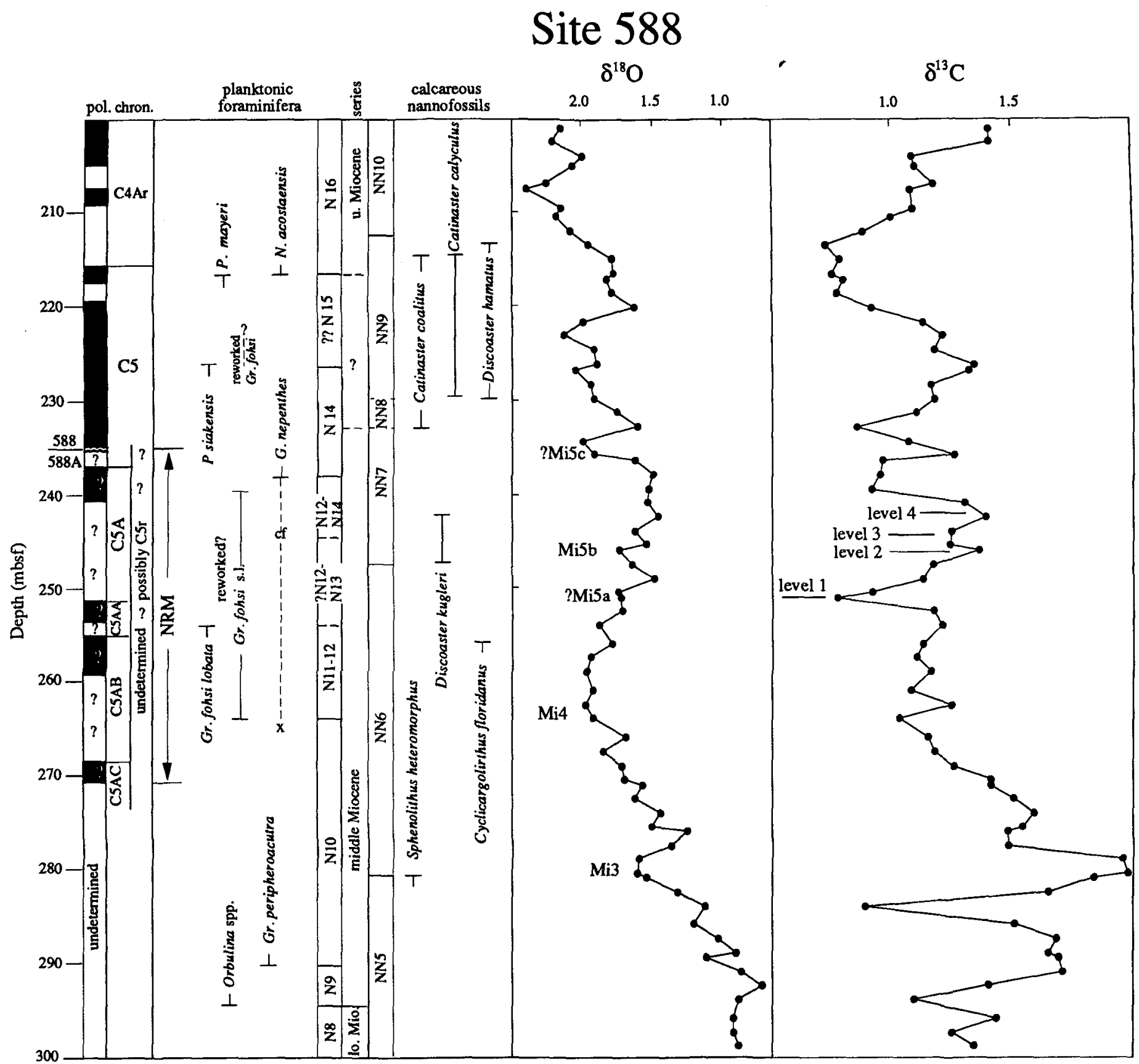

Figure 9. Magnetostratigraphy (Barton and Bloemendal, 1986), biostratigraphy (Lohman, 1986; Jenkins and Srinivasan, 1986), and isotopic stratigraphy (Kennett, 1986) of Site 588 (southwest Pacific, 26 ${ }^{\circ} \mathrm{S}$ ). Levels 1-4 correspond to the carbon isotopic levels described at Buff Bay (Fig. 6); Mi3-Mi5 are the oxygen isotopic zones of Miller and others (1991); a, b, and c are informal subdivisions of Miocene oxygen isotopic zone Mi5 used here. Note that polarities at Hole $588 \mathrm{~A}$ are all based on natural remanent magnetization data; the left-hand Chron column shows the interpretation of Barton and Bloemendal (1986) and the right-hand column is from this study. $x=$ isolated occurrence.

(3) The magnetobiostratigraphic correlations and ages of the FO of D. hamatus, LO of $P$. mayeri, and FO of $C$. coalitus would be significantly different from those reported by Miller and others (1985) and used by Berggren and others (1985).
This hypothesis is not supported by the correlations provided by carbon isotope Levels 3 and 4 and oxygen isotopic Zones Mi5b and Mi5c (Figs. 7 and 8), although the correlations of Level 2 and Zone Mi5a could be consistent with it.
Hypothesis III. If we accept the published magnetochronology at Site 563 (Miller and others, 1985) and the unconformity at $272 \mathrm{~m}$ at Buff Bay (Aubry, 1993), then at least five biostratigraphic first and last occurrence levels are diachronous (solid line, Fig. 8). This 


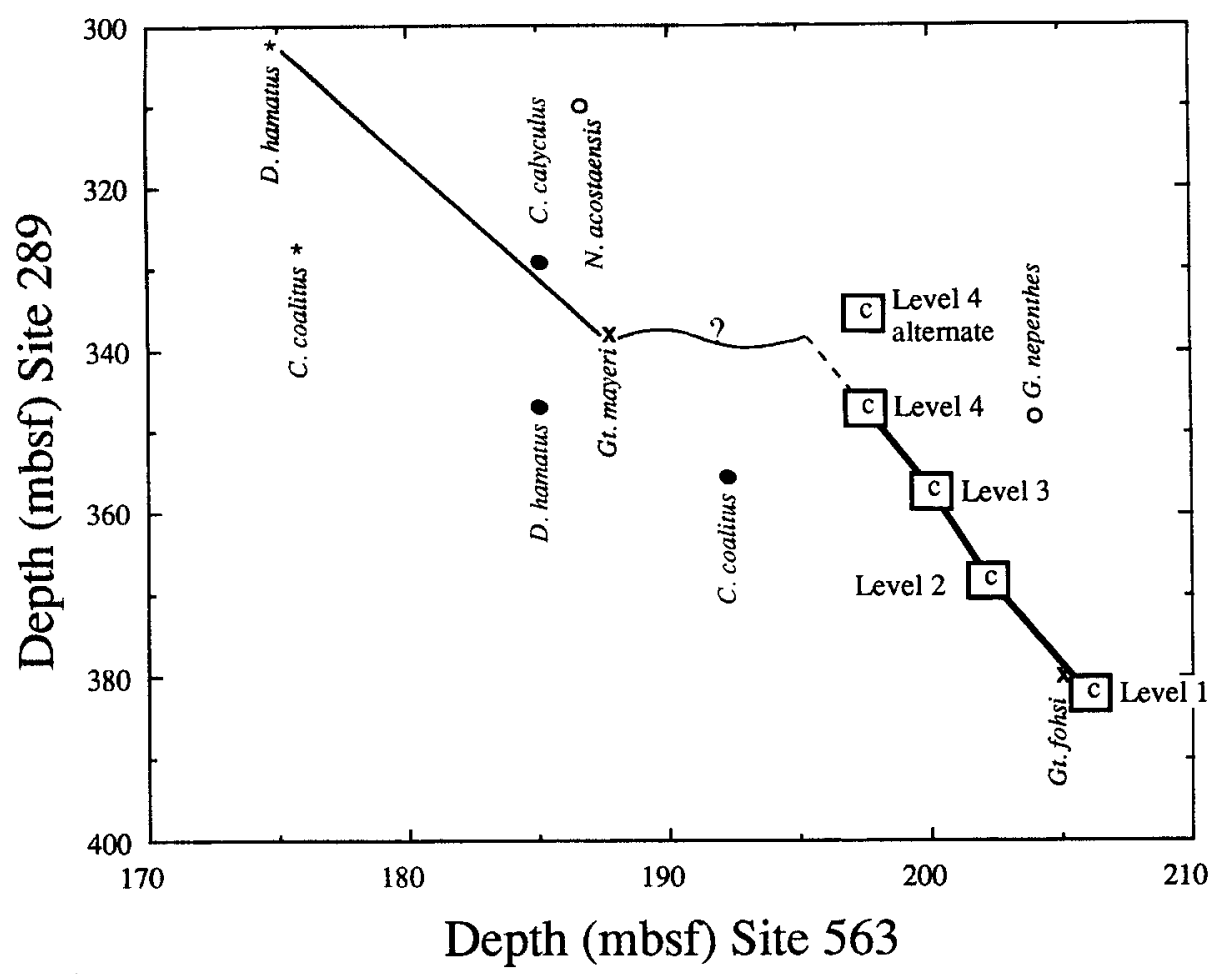

Figure 10. Depth-depth plot of Site 289 versus 563. Stable isotopic correlations (c = carbon) are used to develop a line of correlation, and the diachrony of taxa is illustrated.

is our favored interpretation based on isotopic correlations of Levels 3 and 4 and Zones Mi5b and Mi5c (Fig. 8), and it requires the following.

(1) The FO of $D$. hamatus was delayed in the subtropics. This is supported by the relations at Site 289 , which also indicate a delayed subtropical first occurrence (Fig. 10).

(2) The LO of $P$. mayeri was premature at Buff Bay.

(3) The FO of $C$. coalitus was delayed in the subtropics. This is also indicated by comparisons with Site 289 (Fig. 10).

(4) The FO of G. nepenthes was delayed at tropical sites (Fig. 8). This is also indicated by comparisons with Site 289 (Fig. 10) and requires that Zone N14 be short in the tropics and long in the subtropics.

(5) The FO of $D$. kugleri was delayed in the tropics.

(6) Very high sedimentation rates occurred in Chron C5r.2n in Buff Bay $(\sim 240$ $\mathrm{m} / \mathrm{m} . \mathrm{y}$.).

The isotopic correlations of Levels 3 and 4 and Zones Mi5b and Mi5c support the interpretation that the five taxa discussed above had diachronous first and last occurrences and support Hypothesis III. The amount of diachrony is difficult to specify because the Berggren and others (1985) time scale relied on the Site 563 correlations for the late middle to early late Miocene interval and because the GPTS for this interval has undergone large changes since 1985 (Cande and Kent, 1992).

To estimate the amount of diachrony, we compute age estimates for middle to late Miocene planktonic foraminifera and nannoplankton (Table 1, Figs. 5 and 11) using magnetobiostratigraphic correlations at Site 563 (Fig. 3) and the GPTS of Cande and Kent (1992). The biostratigraphic age estimates are tentative because they are based on Site 563; the magnetostratigraphy of the section from 240 to $210 \mathrm{~m}$ (Fig. 3) at Site 563 contains a predominance of normal polarities compared to the GPTS, and identification of upper middle Miocene magnetochronozones at Site 563 relies on isotopic correlations (Fig. 3); Wright and Miller, 1992). However, this section still provides the only reliable middle to early late Miocene correlations among planktonic foraminifera, calcareous nannoplankton, and magnetostratigraphy. Despite this shortcoming, Figure 11 provides a good estimate of the relative diachrony of taxa and a reasonable estimate of the absolute diachrony.
Although tentative, the age estimates for some of the taxa (Figs. 5 and 11; Table 1) agree well with other proposed revisions to Berggren and others (1985). For example, Backman and others (1990) suggested an age of $12.2 \mathrm{Ma}$ for the FO of $D$. kugleri versus the age of 13.1 Ma of Berggren and others (1985). Our age estimate (12.2 Ma) agrees remarkably well with the estimate of Backman and others (1990) at ODP Site 710 (tropical Indian Ocean). They also calibrated the FO of $D$. hamatus to the base of a thick normal magnetozone identified as Chronozone C5n. This is the same correlation observed at Site 563; however, the section below the FO of $D$. hamatus at Site 710 contains slumps, and Backman and others (1990) cautioned that this may not be its first true occurrence. Nevertheless, results from Site 845A (eastern equatorial Pacific) also shows that $D$. hamatus first occurs at the base of a thick normal magnetozone identified as Chronozone C5n (D. Schneider, unpub. data; I. Raffi, unpub. data); these studies indicate that this taxon may have appeared in the tropical Indian and Pacific Oceans at ca. $10.85 \mathrm{Ma}$ (using CK92). At Buff Bay, D. hamatus appeared prior to this at ca. 11.4 Ma (Figs. 5 and 11).

The diachrony in the FO of $G$. nepenthes and $D$. kugleri is modest ( $\sim 300$ k.y.). These taxa may be used in tropical and subtropical zonations with the understanding that the zonal boundaries are slightly diachronous. The diachrony in the LO of $P$. mayeri, the FO of $D$. hamatus, and the FO of $C$. calyculus is $\sim 0.5$ m.y. Although these taxa may be used for endemic zonations, tropical zonations using these criteria cannot be applied to the subtropics. For example, Zone $\mathrm{N} 15$ (from the LO of $P$. mayeri to the FO of $N$. acostaensis) is a valid zone in the tropics and thick accumulations of this zone have been noted (for example, Fig. 2; see Berggren, 1993, for discussion). However, previous studies of Sites 563 and 558 (Miller and others, 1985) suggested that this zone does not exist in the subtropical North Atlantic due to the diachronous LO of $P$. mayeri. Note that Zone N15 exists in the subtropical Pacific (for example, Site 588) due to the diachronous LO of $N$. acostaensis in this ocean (Keller and others, 1982; Barron and others, 1985). Although the diachrony of the FO of $G$. nepenthes is modest ( $\sim 300$ k.y.), this event can only be used as a zonal criteria for endemic zonations. This is because Zone $\mathrm{N} 13$ (from the LO of $G$. fohsi ssp. to the FO of $G$. nepenthes) is a valid zone in the tropics but does not exist in the subtropical North 


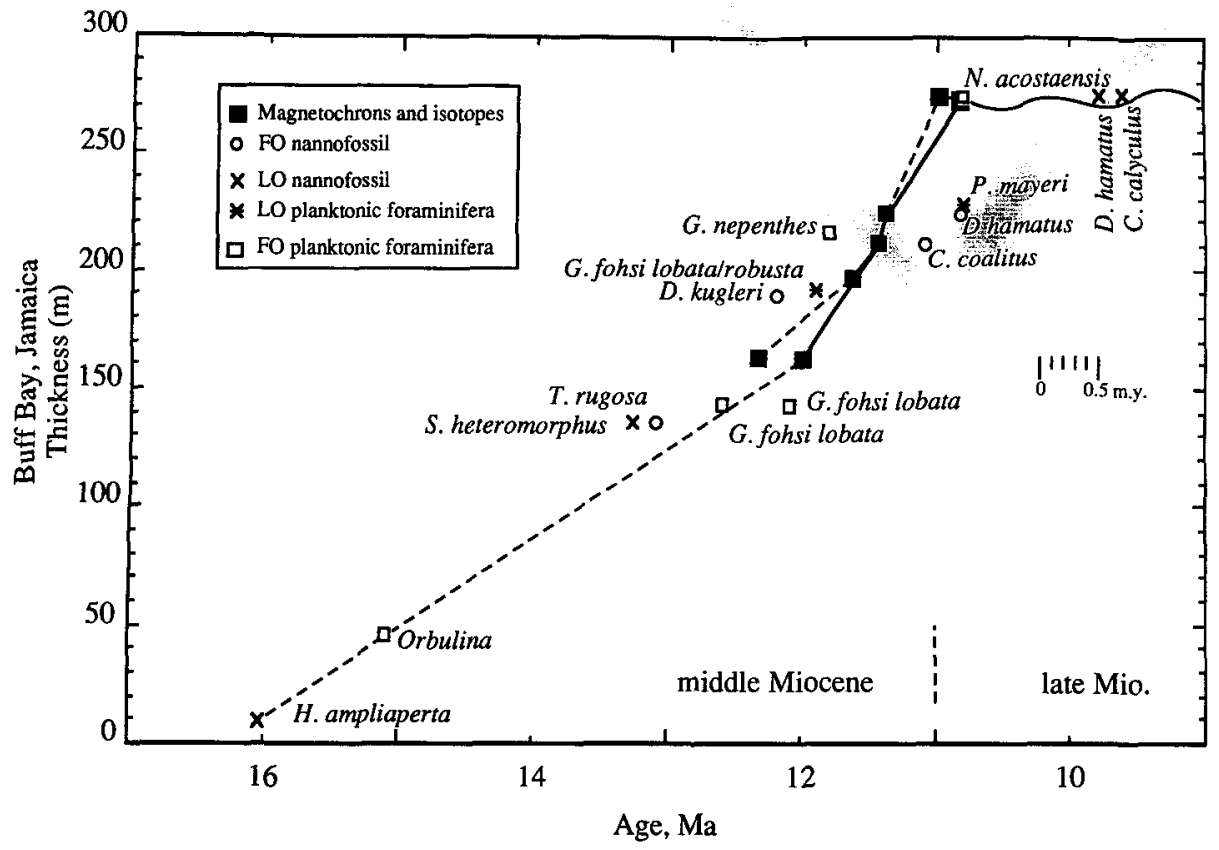

Figure 11. Age-depth diagram for Buff Bay sections constructed using the age calibrations developed here (Table 1) using subtropical Site 563 and the geomagnetic polarity time scale of Cande and Kent (1992). Scale in center-right is 0.5 m.y. and illustrates that the diachrony required by hypothesis III is 0.3-0.5 m.y. Each point that falls off of the lines of correlation are diachronous at Buff Bay relative to the time scale constructed using the Site 563 magnetobiostratigraphy.

Atlantic due to the diachronous FO of $G$. nepenthes. This also implies that Zone N13 is a thin zone where present.

Our conclusion that there are significant differences in ranges of taxa between the tropics and subtropics is not a surprise. Latitudinal diachrony in Cenozoic microfossil ranges has been documented by Johnson and Nigrini (1985), Weaver and Clement (1986), Dowsett (1988), Hess and others (1989), and Wei (1993), along with intraand interbasinal diachrony (Johnson and Nigrini, 1985; Dowsett, 1988). It is clear that many diagnostic zonal taxa are actually diachronous (for example, Globorotalia truncatulinoides, Dowsett, 1988; several late Neogene nannofossil taxa, Wei, 1993), although many have been shown to be synchronous within a very short duration $(\sim 0.02$ m.y. for several late Neogene nannoplankton taxa; Wei, 1993). It is critical to evaluate the synchrony/diachrony of taxa against an independent chronology, including other biostratigraphy (Johnson and Nigrini, 1985), magnetochronology (for example, Miller and others, 1991a), Sr-isotope stratigraphy (for example, Hess and others, 1989), oxygen isotopic stratigraphy (for ex- ample, Wei, 1993), and carbon isotopic stratigraphy (this study).

Mid- and high-latitude zonations have been developed for the Neogene because of the scarcity/absence of tropical markers at higher latitudes (for example, Kennett and Srinivasan, 1983). We have shown that many Miocene tropical markers are useful in biostratigraphic zonations at midlatitudes (for example, Site 563), and some even extend to latitudes as high as $43^{\circ} \mathrm{N}$ (for example, Site 608 ). In the Paleogene, low-latitude markers extended to even higher latitudes, but the increase in latitudinal thermal gradients during the Oligocene-Miocene (for example, Savin and others, 1985) resulted in increased bioprovincialization and restriction of tropical forms to lower latitudes (for example, Wright and Thunell, 1988). The late middle Miocene was an interval of cooling and increased latitudinal thermal gradients (for example, Savin and others, 1985; Wright and Thunell, 1988) that undoubtedly contributed to the diachrony documented here. We conclude that ranges of several taxa are useful for endemic tropical or subtropical zonations, but that late middle Miocene biostratigraphic correlations between low and midlatitudes were affected by these paleoceanographic changes.

The specter of diachrony raises concerns about using biostratigraphy in time correlations. Such concerns are exaggerated and we would still consider most biostratigraphic zonal markers useful proxies for time. Most magnetobiostratigraphic studies have shown that biostratigraphic markers are synchronous within better than $0.3-0.5$ m.y. (for example, Miller and others, 1991a), and we argue that this is the typical biostratigraphic resolution available for much of the Cenozoic. Even in the example presented here, we document that diachrony, although real, is relatively minor (0.3-0.5 m.y.).

The diachrony of zonal markers requires revisions to geological time scale. Our revision (Fig. 4) to the late middle to early late Miocene time scale is still preliminary because (1) the ages of the FO of N. acostaensis and the LO of D. hamatus, the zonal criteria for the bases of Zone N16 and NN10, respectively, are not well constrained in the tropics; (2) the age estimates derived here should be confirmed against other tropical and subtropical locations; and (3) the position of the middle/late Miocene boundary is uncertain. The base of the stratotype Tortonian (= base of the upper Miocene) is poorly defined. At the stratotype at Rio Mazzapiedi, $D$. hamatus occurs in a single sample near the base (Sample 4 of Cita and others, 1965); this same level contains $N$. acostaensis and thus this sample is Zones N16 and NN9. This sample was interpreted as recording the LO of D. hamaius (that is, uppermost Zone NN9) and the FO of $N$. acostaensis (that is, basal Zone N16) by Cita and others (1965), but Berggren and others (1985) and Rio and others (1990) noted that preservation below Sample 4 is poor and the position of the basal Tortonian is uncertain. The section below Sample 4 could be interpreted as Zone NN8 (that is, prior to the sole occurrence of $D$. hamatus; Miller and others, 1985; Berggren and others, 1985) or Zone NN9 (Rio and others, 1990). We suggest that the base of the Tortonian lies within subtropical Zone NN8 immediately prior to the FO of $N$. acostaensis; if so, then the base of the upper Miocene is ca. $11 \mathrm{Ma}$ and correlates to Chron C5r.1n (Fig. 4). However, it is equally possible that the base of the Tortonian is uppermost Zone NN9 and lower tropical Zone N16; if so, it could be as young as $10 \mathrm{Ma}$. Resolving this difference of 1 m.y. in the age of the middle/late Miocene boundary will require designation of a boundary stratotype. 


\section{CONCLUSIONS}

Field studies of middle-upper Miocene chalks exposed at Buff Bay, Jamaica, revealed biostratigraphic relationships between foraminiferal and nannofossils that are very different from those in subtropical North Atlantic sites used to construct the global time scale. The interpretation is further complicated by the association of Zone NN9 with normal magnetozones in the North Atlantic and a reversed magnetozone in Jamaica; these magnetobiostratigraphic relationships require either significant diachrony of taxa or mutually exclusive hiatuses in the North Atlantic sites versus Jamaica. Stable isotopic stratigraphy allowed us to evaluate the diachrony and hiatus/ unconformity hypotheses and to conclude that several nannofossil and foraminiferal taxa are diachronous by $\sim 0.3-0.5$ m.y. Stable isotopic studies are thus proving to be valuable in evaluating Miocene correlations on the million year scale. The complicated stratigraphic problem addressed here could be solved only by integrating biostratigraphic, magnetostratigraphic, and isotopic studies.

\section{ACKNOWLEDGMENTS}

This study developed from a joint field program to Jamaica in 1987 , and field support was provided by Unocal (G. Jones, R. C. Tjalsma, and C. Stuart). We thank members of the field party, especially C. Stuart, who measured the section and provided us with lithologic descriptions. We thank M.-P. Aubry and W. A. Berggren for discussions of the problem. Benthic foraminiferal studies by M. E. Katz on the Buff Bay section contributed to the isotopic studies presented here. We thank M.-P. Aubry, J. A. Barron, B. H. Corliss, W. A. Berggren, and B. P. Flower for reviews. Work was supported by National Science Foundation Grant OCE91 000933 (Miller) and a consortium of oil companies (BP, Chevron, Marathon, Texaco, and Unocal). This is Lamont-Doherty Earth Observatory Contribution No. 5260 .

\section{REFERENCES CITED}

Aubry, M.-P., 1993, Calcareous nannofossil stratigraphy of the Neogene formations of eastern Jamaica: Geological Society of America Memoir 182, p. 131-178.

Backman, J., Schncider, D. A., Rio, D., and Okada, H., 1990 Neogene low-latilude magnetostratigraphy from Site 710 and revised age cstimates of Miocene nannofossil datum events, in Duncan, R. A., Backman, J., and others, Proceedings, ODP, Scientific Results, Volume 115: College Station, Texas, Ocean Drilling Program, p. 271-276.

Barron, J., Keller, G., and Dunn, D., 1985, A multiple microfossil biochronology for the Miocene: Geological Society of America Memoir 163, p. 21-36.

Barton, C. E., and Bloemendal, J., 1986, Paleomagnetism of sediments collected during Leg 90, southwest Pacific: Initia Reports of

Berggren, W. A., 1992, Paleogene planktonic foraminifer magnetobiostratigraphy of the southern Kerguelen Plateau (ODP Sites 747-749): Proceedings, ODP, Scientific Results, Part B: $551-568$.

Berggren, W. A., 1993, Neogene planktonic foraminiferal biosiratigraphy of eastern Jamaica: Geological Society of siratigraphy of eastern Jamaica:
America Memoir 182, p. 179-217.

Berggren, W. A., and Van Couvering, J. A., 1974, The late Neogene: Palaeogeography, Palaeoclimatology, Palaeoecology, v. 16, p. $1-216$

Berggren, W. A., Kent. D. V., and Van Couvering, J. A., 1985 Neogene geochronology and chronostratigraphy, in Snelling, N. J., ed., Geochronology and the geologic time scalc Geological Socicty of London Memoir 10, p. 211-260.

Blow, W. H., 1969, Late middle Eocene to Recent planktonic foraminiferal biostratigraphy, in Bronnimann, R., and Renz, H. H., eds., Proceedinys, First International Conference on
Planktonic Microfossils, Geneva, 1967, Volume 1: Leiden,

Bronnimann, P., and Resig. J., 1971, A Neogene globigerinacea biochronologic time-scale of the southwestern Pacific Deep Sea Drilling Project, v. 7. p. $1235-1469$.

Cande, S. C., and Kent, D. V., 1992, A new geomagnetic polarity time scale for the Late Cretaceous and Cenozoic: Journal of Geophysical Research, v. 97, p. 13917-13951.

Cita, M. B., Premoli-Silva, L, and Rossi, R., 1965, Foraminifer planktonici del Tortoniano tipo: Revista Italiana de Paleontologia e Stratigrafia, v. 71, p. 217-308.

Clement, B., and Robinson, F., 1986, The magnetostratigraphy of Lcg 94 sediments: Initial Reports of the Deep Sea Drilling Project, v. 94, p. 635-650.

Dowsett, H.J., 1988, Diachrony of late Neogene microfossils in the southwest Pacific Ocean: Application of the graphic corre

Iation technique: Paleoceanography, v. 3, p. 209-222.
Duncan, R. A., Backman, J., and others, 1988, Proceedings, ODP, Scientific Results, Volume 115: College Station, Texas, Scientific Results, Volume 115
Ocean Drilling Program, $1085 \mathrm{p}$

Gartner, S., 1991, Miocene nannofossil chronology in the North Atlantic, DSDP Site 608: Marine Micropaleontology, v. 18, p. $307-331$.

Flower, B. P., and Kennett, J. P., 1993, Middle Miocene oceanclimate transition: High-resolution oxygen and carbon isotopic record from Deep Sea Drilling Project Site 588A topic record from Deep Sea Drilling Project Site 588A
southwest Pacific: Paleoceanography, v. 8, p. 811-843.

southwest Pacific: Paleoceanography, v. 8, p. 811-843.
Foster, J. H., and Opdyke, N. D., 1970, Upper Miocene to Recent magnetic stratigraphy in deep-sea sediments: Journal of magnetic stratigraphy in deep-sea sedime

Haq, B. U., Hardenbol, J., and Vail, P. R., 1987, Chronology of fluctuating sea levels since the Triassic ( $250 \mathrm{~m}$

ago to present): Science, v. 235, P. 1156-1167.
Heider, F., Leitner, B., and Inokuchi, H., 1992, High southern latitude magnetostratigraphy and rock magnetic properties of sediments from Sites 747, 749, and 751: Proceedings
ODP, Scientific Results, Volume 120: College Station, Texas, Ocean Drilling Program, p. 225-246.

Heirtzler, J. R., Dickson, G. O., Herron, E. M., Pitman, W. R., Le Pichon, X., 1968, Marine magnetic anomalies, geomagnetic field reversals, and motions of the ocean floor and continents: Journal of Geophysical Research, v. 73, p. 2119-2136.

Hess, J., Stott, L. D., Bender, M. L., Kennett, J. P., and Schilling J.-G., 1989, The Oligocene marine microfossil record: Age assessments using strontium isotopes: Paleoceanography, v. 4, p. $655-679$

Hilgen, F. J., 1991, Extension of the astronomically calibrated (polarity) time scatle to the Miocene/Pliocene boundary: Earth and Planetary Science Letters, v. 107, p. 349-368

, D. A., and Woodruff, F., 1994, Vartations in the strontium isotopic ratio of seawater during the Miocene: Strati-
graphic and geochemical implications: Paleoceanography praphic and $405-426$.

Imbrie, J., and eight others, 1984, The orbital theory of Pleistocene climate: Suppstt from a revised chronology of the marine
$8^{18} \mathrm{O}$ record, in Berger, A. L., Imbrie, J., Hays, J. D., Kukla, $\delta$
G., and Salizman, B., eds., Milankovitch and climate, Part I: Dordrecht, Netherlands, ReideI, p. 269-305.

Irving, E., and Irving, G. A., 1982, Apparent polar wander paths Carboniferous through Cenozoic and the assembly of Gondwana: Geophysical Surveys, v. 5, p. 141-188.

Jenkins, D. G., and Srinivasan, M. S., 1986, Cenozoic planktonic foraminifers from the equator to the Sub-Antarctic of the Southwest Pacific: Initial Reports of the Deep Sea Drilling Project, v. 90 , p. $795-834$

Johnson, D., and Nigrini, C., 1985, Time-transgressive late Cenozoic radiolarian events of the Equatorial Indo-Pacific: Sci-

ence, v. 230, p. 538-540.
Katz, M. E., and Miller, K. G., 1993, Miocene-Pliocene bathyal benthic foraminifera, Buff Bay, Jamaica: Implications for
uplift: Geological Society of America Memoir 182, p. 219-254.

Keller, G., Barron, J. A., and Burckle, L. H., 1982, North Pacific late Miocene correlations using microfossils, stable isotopes, percent $\mathrm{CaCO}_{3}$ and magnetostratigraphy: Marine Micropa-
leontology, v. 3, p. 301-345.
Kennett, J. P., 1986, Miocene to early Pliocene oxygen and carbon isotope stratigraphy in the southwest Pacific, Deep Sea Dril ling Project Leg 90: Neogene and Quaternary: Initial Re-

ports of the Deep Sea Drilling Project, v. 90, p. 1383-1412.
Kennett, J. P., and Srinivasan, S., 1983, Neogene planktonic foraminifera: Stroudsberg. Pennsylvania, Hutchinson Ross, $265 \mathrm{p}$.

Kirschvink, J. L., 1980, The least-squares line and plane and the analysis of paleomagnetic data: Royal Astronomical Society Geophysical Journal, v. 62, p. 699-718.

Kroenke, L. W., Berger, W., and others, 1993, Proceedings, ODP, Initial Reports, Volume 130: College Station, Texas, Ocean

Drilling Program, 1240 p.
LaBrecque, J. L, Kent, D.V., and Cande, S. C., 1977, Revised magnetic polarity time scale for Late Cretaceous and $\mathrm{Ce}$ nozoic time: Geology, v. 5 , p. $330-335$.

Lohman, W. H., 1986, Calcareous nannoplankton biostratigraphy of the southern Coral Sea, Tasman Sea, and southwestern Pacific Ocean, Deep Sea Drilling Project Leg 90: Neogene
and Quaternary: Initial Reports of the Deep Sea Drilling Project, v. 90, p. 763-794

Loutit, T. S., Pisias, N. G., and Kennett, J. P., 1983, Pacific Miocene carbon isotope stratigraphy using benthic foraminifera: Earth and Planetary Science Letters, v. 66, p. 48-62.

Martini, E., and Worsley, T., 1971, Tertiary calcareous nannoplankton from the western equatorial Pacific: Initial Reports of the Deep Sea Drilling Project, v. 7, p. 1471-1507.

Miller, K. G., and Fairbanks, R. G., 1985, Oligocene to Miocene global carbon isotope cycles and abyssal circulation changes in Sundquist, E. T., and Broecker, W. S., eds., The carbon cycle and atmospheric $\mathrm{CO}_{2}$ : Natural variations, Archean to Present: American Geophysical Union Geophysical Monograph 32, p. $469-486$.

Miller, K. G., and Kent, D. V., 1987, Testing Cenozoic eustatic changes: The critical role of stratigraphic resolution: Cushman Foundation for Foraminiferal Research Special Publication 24, p. $51-56$

Miller, K. G., Aubry, M.-P., Khan, J., Melillo, A. J., Kent, D.V. and Berggren, W. A., 1985, Oligocene to Miocene biostratigraphy, magnetostratigraphy, and isotopic stratigraphy Miller, K. G., Feigenson, M. D., and Wright, J. D., 1991a, Lower to middle Miocene isotope $\left({ }^{87} \mathrm{Sr}{ }^{86} \mathrm{Sr}, \delta^{18} \mathrm{O}, \delta^{13} \mathrm{C}\right)$ standard
to section, DSDP Site 608: Paleoceanography, v. 3, p. 223-233.

Miller, K. G., Wright, J. D., and Fairbanks, R. G., 1991b, Unlocking the Ice House: Oligocene-Miocene oxygen isotopes, eustasy, and margin er

Pisias, N. G., Shackleton, N. J., and Hall, M. A., 1985, Stable isotope and calcium carbonate records from hydraulic piston cored Hole 574A: High-resolution records from the middle Miocene: Initial

Rio, D., Fornaciari, E., and Raffi, I., 1990. Late Oligocene through early Pleistocene calcareous nannofossils from western equatorial Indian Ocean (Leg 115): Proceedings, ODP, Scientific Results, Volume 115: College Station, Texas, Ocean Drilling Project, p. 175-236.

Robinson, E., 1969, Geological field guide to Neogene section in Jamaica, y. 10, p. 1-24.

Ruddiman, W. F., Sarnthein, M., and others, 1989, Proceedings, ODP, Initial Reports, Volume 108: College Station, Texas, Ocean Drilling Program, $1073 \mathrm{p}$

Ryan, W. B. F., Cita, M. B., Dreyfus Rawson, M., Burckle, L. H and Saito, T., 1974, A paleomagnetic assignment of Neogene stage boundaries and the development of isochronous datum planes between the Mediterranean, the Pacific, an Indian Oceans in order to investigate the response of the world ocean to the Mediterranean salinity "salinity crisis":
Rivista Italiana de Paleontologia e Stratigrafia, v. 80 , Rivista Italiana

Savin, S. M., and eight others, 1985, The evolution of Miocene surface and near-surface marine temperatures: Oxygen isotopic evide
p. $49-82$,

Shackleton, N. J., and Kennett, J. P., 1975, Paleotemperature history of the Cenozoic and initiation of Antarctic glaciation: Oxygen and carbon isotopic analyses in DSDP Sites 277 279, and 281: Initial Report

Shackleton, N. I., Berger, A., and Peltier, W. R., 1990 An alternative astronomical calibration of the lower Pleistocene time scale based on ODP Site 677: Transactions of the Royal Society Edinburgh, v. 81, p. 251-261.

Shackleton, N. J., and others, in press, Proceedings Ocean Drilling Program, Scientific Results, Volume 138: College Station, Texas, Ocean Drilling Program.

Shafik, S., 1975, Nannofossil biostratigraphy of the southwest $\mathrm{Pa}$ cific, Deep Sea Drilling Project, Leg 30: Initial Reports of the Deep Sea Drilling Project, v. 30 , p. $549-598$.

Srinivasan, M. S., and Kennett, J. P., 1981, Neogene planktonic foraminiferal biostratigraphy: Equatorial to subantarctic, South Pacific: Marine Micropaleontology, v. 6, p. 499-534.

Vincent, E., and Berger, W. H., 1985, Carbon dioxide and pola cooling in the Miocene: The Monterey hypothesis, in Sundquist, E. T., and Broecker, W. S., eds., The carbon cycle and atmospheric $\mathrm{CO}_{2}$ : Natural variations, Archean to Present: American Geophysical Union Geophysical Mono-
graph 32. $455-468$.

graph 32, p. 455-468.
Weaver, P. P. E., and Clement, B. M., 1986, Synchroneity of Plio- 
cenle planktonic foraminiferal datums in the North Atlantic: Marine Micropaleontology, v. 10, p. 295-308

Wei, W. 1993, Calibration of Pliocene-Pleistocene nannofossil events with oxygen isotope stratigraphy: Paleoceanography, v. 8, p. 85-99.

Winterer, E. L., and others, 1971 , Initial Reports of the Deep Sea Drilling Project, v. 7, $1757 \mathrm{p}$.

Wise, S. W., Schlich, R., and others, 1989, Proceedings, ODP, Initial Reports, Volume 120: College Station, Texas, Ocean Drilling Program, $648 \mathrm{p}$.
Woodruff, F, and Savin, S. M.,1989, Miocene deep-water ocean-

. F. M. 1991, Mid-Miocene isot ruff, F., and Savin, S. M., 1991, Mid-Miocene isotope stratigraphy in the deep sea: High-resolution correlations, paraphy, v. $6,0.755-806$.

Wright, J. D., and Miller, K. G., 1992, Miocene stable isotope stratigraphy, Site 747, Kerguelen Plateau: Proceedings, ODP, Scientific Report, Volume 120: College Station, Texas, Ocean Drilling Program, p. 855-866.
Wright, J. D., and Thunell, R. C., 1988, Neogene planktonic foraminiferal biogeography and paleoceanography of the Indian Ocean: Micropaleontology, v. 34, p. 193-216.

Wright, J. D., Miller, K. G., and Fairbanks, R. G., 1992, Early and middle Miocene stable isotopes: Implications for deepwater circulation and climate: Paleoceanography, v. 7, p. 357-389.

ManusCript Received by the SOCIety OCtoBer 8, 1993

Revised MaNuscript ReCEIVEd March 28, 1994

MANUSCRIPT ACCEPTED JUNE 13, 1994 